\title{
Nervous nation: Fear, conflict and narratives of fortified domestic architecture on the Queensland frontier
}

\author{
Heather Burke, Ray Kerkhove, Lynley A. Wallis, \\ Cathy Keys and Bryce Barker
}

\begin{abstract}
The frontier of nineteenth- and twentieth-century Australia was a place in which colonists routinely lived in fear of retaliation by the Aboriginal peoples whose traditional lands they had forcibly dispossessed. It has been suggested this concern manifested itself in domestic architecture, in both active and passive defensive strategies designed to afford protection against various forms of potential attack. Yet there remains a lack of substantive research to support such assertions. In this article, we present an analysis of accounts drawn from a range of sources of 97 domestic structures across Queensland with claims for defensive features. Although suggesting that fortified domestic structures were more common than previously envisaged, our review indicates that defensive features were usually minimal - holes in walls and barrable doors, windows or other ports of entry - reflecting the often expedient nature of the structures themselves. First-hand accounts of these buildings are rare, although not entirely absent, with most written accounts being reminiscences told in hindsight by later descendants, resulting in both distortions and myth-building. Accounts of fortified domestic structures peak in the decades following Federation and through both World Wars as the newly minted Australian nation explicitly engaged in nation-building and constructing the 'glorious pioneer' narrative.
\end{abstract}




\section{Introduction}

A recent survey of the documentary evidence relating to the frontier in colonial Van Diemen's Land, Australia, argued that 'fear was the most significant of the emotions characterising the wartime experiences of colonists'. ${ }^{1}$ Colonists were afraid for their financial livelihoods, property, stock and personal physical safety, as well as that of others around them, employing a range of defensive tactics to protect themselves. Clements and Gregg went further to argue that this 'atmosphere of terror and anxiety':

forced numerous architectural and behavioural changes. Remote residences became 'fortresses' and few ventured beyond their huts without guns, dogs or companions. In extreme cases, fear even drove people off their farms. ${ }^{2}$

In identifying defensive behaviours employed by colonists to protect life and property (including laying turf on roofs to prevent fire, enclosing buildings within log palisades or high brick walls, extensive clearing around properties, incorporating apertures into walls to accommodate gunfire and placing windows higher up the walls than usual), Clements and Gregg connected fear with a range of material correlates. ${ }^{3}$

They were not the first to do so. Decades earlier, Reynolds and Loos alluded to the state of 'communal insecurity' among nineteenth-century Europeans in Queensland, regardless of whether they were small groups living in isolation or residents of towns. ${ }^{4}$ Likewise, Evans cited direct references from colonists in the more remote outposts of the frontier that spoke directly to the 'strain and terror involved in contending with the unknown wilds'. ${ }^{5}$ Previous historical work also attempted to link a necessity for personal defence with the incorporation of defensive features into domestic architecture, some going so far as to claim that, "Indeed, "solidly built slab homesteads and huts with loopholes pierced in the thick walls for rifles" would seem to have been the frontier norm in South-East Queensland'. ${ }^{6}$

Occasional studies of surviving colonial period structures by archaeologists, however, have been more conditional. ${ }^{7}$ While both Grguric and Wiltshire, Litster and Rigney identified particular architectural features that could have functioned defensively, such as small openings in walls in structures in South Australia and the Northern Territory, they also noted that these were common architectural

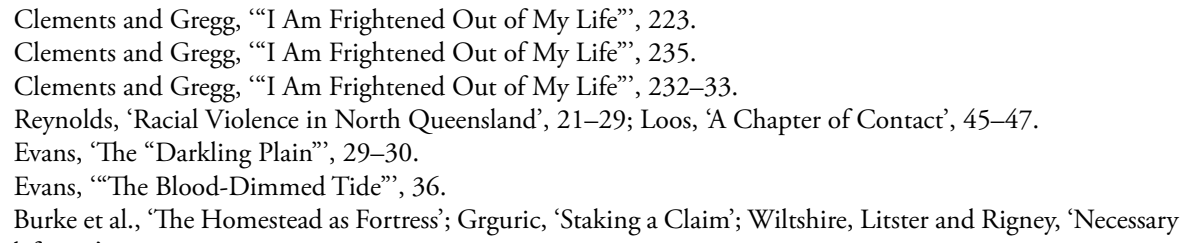


elements and therefore might have only been used opportunistically for defence. In the case of Wiltshire, Litster and Rigney, they argued that the defensive function ascribed to vertical slits in an outbuilding on the Coorong peninsula was a later reinterpretation, probably functioning as a mnemonic to cohere Aboriginal people's recollections of violence in the wider region. ${ }^{8}$ Except for Kerkhove's typology, which aligns these structures with the militarised nature of early Queensland, other studies have argued that such equivocality renders the subsequent romanticising of such features as symbolic of the frontier a more relevant measure for understanding past and present settler-Aboriginal relations than the 'truth' of a defensive purpose itself.'

A lack of research in this area is symptomatic of the political and perhaps psychological difficulties that drive contemporary Australian memory of the colonial period. ${ }^{10}$ From the slavery-forts of coastal Africa to the log stockades of the American West, domestic and military fortifications targeting Indigenous peoples have been part and parcel of European colonial expansion. ${ }^{11}$ By contrast, architectural historians maintain that domestic Australia had no such structures. ${ }^{12}$ Although Australian colonies had coastal defences and penal fortifications, their interiors had little in the way of unambiguous defensive structures and no system of strategically placed, centralised forts, as was the case in the United States. ${ }^{13}$ Instead, the internal frontier was a much more diffuse and malleable borderland animated by the personal choices and actions of settlers and itinerants and, in some colonies - especially Queensland - government agents such as the Native Mounted Police.

By populating this frontier borderlands, civilian settlers placed themselves at the 'front line' between Aboriginal and non-Aboriginal realms. It is therefore unsurprising that many of the spaces involved in frontier war skirmishes are described as domestic. A desktop study of frontier domestic structures provides an important means of probing patterns in purported structural defences - were such buildings commonplace? Who built them, where and when? What materials were they built from? What were the most common features? Such a survey can help to understand the scale and nature of domestic fortification and, by adopting an historical (and historiographical) perspective, enable some assessment of the reliability of tales of domestic fortification over time. As such, this article begins with an assessment of the nature and extent of fears about attack and uses this to focus more closely on the potential behavioural consequences this fear may have engendered through an analysis of accounts of potentially fortified structures across Queensland.

\footnotetext{
8 Wiltshire, Litster and Rigney, 'Necessary Self-defence?'.

9 Burke et al., 'The Homestead as Fortress'; Kerkhove, 'Frontier War Defences of Early Queensland'.

10 Rowse and Waterton, 'The "Difficult Heritage” of the Native Mounted Police'; Weaver-Hightower, 'Geopolitics,

Landscape and Guilt in Nineteenth-Century Colonial Literature'.

11 Bogart, 'Fort Harrod, Kentucky'; Prickett, 'British Army Field Fortifications of the New Zealand Wars', 111.

12 Garie, 'Australian Colonial Forts', 19.

13 Kerkhove and Keys, 'On the Lookout'.
} 


\section{Fear and lethal danger on the frontier}

Although settler anxieties about the frontier were at times manufactured or amplified, there is little doubt that fear was a common emotion. Fear and anxiety are separate, yet linked states. Fear describes the heightened awareness of an immediate, objective threat; anxiety is the anticipation of a subjective menace that may or may not arise in reality. ${ }^{14}$ There are sufficient historical accounts to support widespread fear and anxiety on the part of settler colonists in many contexts, much of which would have arisen in response to the toll of ongoing conflict.

Regardless of whether and/or how we choose to acknowledge them today, the frontier wars inflicted real and devastating loss and damage. While difficult to calculate, estimates suggest that more than 66,000 Aboriginal people in Queensland were likely to have suffered fatal attacks during the second half of the nineteenth century, constituting around 25 per cent of the population. ${ }^{15}$ Tallies for non-Aboriginal casualties ought to be easier to estimate given that the creators of the archival record had greater concern for their own lives, yet the figures are not much clearer. Early assessments by Reynolds and Loos posited 400-450 and 381-470, respectively, for north Queensland between 1860 and 1900. ${ }^{16}$ Gray later proposed 1,500 European deaths across the continent from c. 1788 to 1930, while Richards suggested 324 Europeans were killed between 1859 and 1904 in Queensland. ${ }^{17}$ Data collected for the Archaeology of the Native Mounted Police project calculated 673 non-Aboriginal deaths in Queensland between 1840 and 1902, with the highest tolls during the 1860 s and 1870 s. $^{18}$ The number of people living in rural contexts in Queensland rose from just over 15,000 to 204,000 between 1861 and 1901, suggesting that, on average, around 1 per cent of the non-Aboriginal population of that period may have been killed by Aboriginal people. ${ }^{19}$

Such calculations are of course retrospective and conducted with due academic rigour to produce a minimum assessment. Those who lived through such periods may have believed the tallies to be much higher, exaggerated by false rumour and premature reports in the press. As Noel Loos has pointed out, however, it is the number of lives thought to have been lost or in imminent danger that was most important in catalysing settler fear. ${ }^{20}$ For instance, William Ogilvie and Roderick Mitchell claimed that on the Maranoa over an 18-month period between 1849 and

14 Bourke, 'Fear and Anxiety', 126, sensu Freud, A General Introduction to Psychoanalysis, 340-43.

15 Evans and Ørsted-Jensen, "I Cannot Say the Numbers that Were Killed”.

16 Reynolds 'Racial Violence in North Queensland', 22; Loos, Invasion and Resistance, 193.

17 Gray, A Military History of Australia; Richards, "A Question of Necessity", Appendix 3.

18 'Events', Frontier Conflict and the Native Mounted Police in Queensland Database, accessed 20 July 2019, doi.org/10.25957/5d9fb541294d5.

19 'Population, Urban and Rural, Queensland, 1861 to 2006', Treasury, Queensland Government, Historical Tables, Demography.

20 Loos, Invasion and Resistance, 45. 
1850 'no less than one-fifth of the white population have been murdered by the aborigines'. ${ }^{21}$ Later in the 1850 s, one commentator claimed the same proportion 'fell in two years' in the Port Curtis district. ${ }^{22}$ Robert Gray, a squatter who settled in the vicinity of Hughenden in the mid-1860s, felt that:

People residing in those districts at the present day ... may think I am exaggerating when I say that during the 'sixties probably ten to fifteen per cent of the white population lost their lives at the hands of the blacks. An officer who was in the native police at that day told me he put the percentage at from twenty to thirty. ${ }^{23}$

Certainly, specific regions and particular time periods saw greater concentrations of loss. Captain John Coley, a resident of Brisbane from 1842, suggested before a Select Committee in 1861 that 250 Europeans had been killed in south-east Queensland between 1824 and 1853; in a 1967 study, Taylor was able to verify from archival documents that at least 161 of these 250 deaths were correct. ${ }^{24}$ Thus, during the 1840s-1850s in south-eastern Queensland, around 8 per cent of the European population had died as a result of Aboriginal attacks.

A dread of being killed or losing friends and kin was further amplified by losses to stock and property, especially when such actions were intended to intimidate and terrify new settlers. John Ker Wilson recalled that as soon as he tried to move north into Queensland near Goondiwindi in 1846 or 1847, Aboriginal groups targeted his stock. At one point, he counted 80 speared carcasses of cattle, 'some of the heads ... cut off and stuck up on sticks'. ${ }^{25}$ In the same time period and place, Margaret Young recalled her intense feeling of vulnerability:

All stock had to be yarded [with] one of the men to guard ... One night they (the blacks) stole 200 of our young ewes, all due to lamb ... Later they returned again, spearing most of the horses, cows and calves ... [We were] so alone and isolated ... the interior silence and black darkness so suddenly engulfed us ... [and] further out, all across the plain ... as far as we could see ... were lights from the fireplaces of the blacks. ${ }^{26}$

21 William Ogilvie and Roderick Mitchell to Richard Purvis Marshall, 24 May 1850, NSW Colonial Secretary Letters Relating to Moreton Bay and Queensland 1822-1860, Reel A2.22, Queensland State Library (hereafter QSL).

22 Maitland Mercury and Hunter River General Advertiser, 6 November 1858, 76.

23 Gray, Reminiscences of India and North Queensland, 78.

24 John Coley, quoted in Queensland Legislative Assembly, Select Committee on the Native Police Force, 19; Taylor, 'Race Relations in South East Queensland', 30.

25 Ward-Brown, 'Native Mounted Police', 2975/8, Box 5273, John Oxley Library.

26 Young, cited in Gunn, Links with the Past, 26-27. 
The culmination of this dread was a range of defensive postures: carrying firearms, monitoring surroundings and, wherever possible, seeking protection in groups. ${ }^{27}$ In 1853, Commissioner of Crown Lands Arthur Halloran, for instance, noted that the inhabitants of Maryborough considered it:

unsafe to go about even near [the] township without fire arms, no one travels from Maryborough to this Station (in an isolated position), distance 4 miles, without being armed - [even] troopers will not go far without fire arms. ${ }^{28}$

The situation was especially frightening for women. ${ }^{29}$ The relegation of women to the domestic sphere tethered them both to the house and its immediate environs and to solitary periods in the absence of a husband, male family member or worker. For example, Lucy Gray, the wife of pastoralist Robert Gray at Hughenden, recounted the anxieties of 'Mrs C' (Alethea Cox Corfield) in the early 1870s, who 'was in perpetual fear of the blacks, \& with good reason for they had murdered her brother down at the Gulf where she had been living \& where they were numerous and dangerous ... when we rode out she saw a black-fellow in every stump or stone half hidden in the grass. ${ }^{30}$

Similarly, Rosa Campbell Praed grew up during the 1850s not far from the site of the infamous Hornet Bank massacre. She claimed her earliest memory was an incident wherein 'a black face' peered between the half-closed shutters of her parents' hut, and her father - himself out hunting for 'the black murderer of an out-shepherd' - returned in the nick of time. ${ }^{31}$ Campbell Praed described her girlhood as a time when:

women practiced at targets with firearms, and the men would ride home with a sinking feeling in their hearts, fearing for their wives and children. Often I heard father describe how each evening coming in from the run, he used in cold fear to mount the hill overlooking the humpy, and draw free breath when he saw it lying quiet and unharmed. ${ }^{32}$

It is reasonable to assume that the perception of threat brought with it certain material consequences, and a review of extant documents provides a useful tool for interrogating the potential existence of such phenomena. We focus here solely on domestic structures, as these dominate the narratives of frontier violence.

\footnotetext{
27 See Reynolds, Frontier, 9-22, for a wide-ranging discussion.

28 Arthur Halloran to Chief Commissioner of Crown Lands, 10 December 1853, NSW Colonial Secretary Letters Relating to Moreton Bay and Queensland 1822-1860, Reel A2.28, QSL.

29 Cf. Card, 'Rape as a Weapon of War'; Diken and Lausten, 'Becoming Abject'; George Bowen to the Duke of Newcastle, 16 December 1861, Letterbook of Despatches to the Secretary of State for the Colonies, Item ID 17671, Queensland State Archives.

30 Gray, 'Life on the Flinders River', 21. Note that this diary entry is not dated, but Edward More Meredyth Huey, Alethea's brother, was killed in 1871 , so it must postdate this.

31 Courier-Mail (Brisbane), 2 April 1949, 2.

32 Campbell Praed, My Australian Girlhood, 352.
} 


\section{Source materials}

The current study was conducted by casting a wide net for images, reminiscences and descriptions of 'fortified' homes and huts. The vast majority of accounts derived from digitised newspapers in the National Library of Australia's Trove resource. Such articles were generally published in smaller, rural newspapers and most consisted of elderly individuals recalling their early experiences or visitors recounting local lore. Other research focused on locating documents that detailed 'early' life in Queensland c. 1840-1910, including manuscripts, theses, memoirs, papers, books and letters within the John Oxley collection (State Library of Queensland), Fryer Library, Welsby collection (Royal Historical Society of Queensland), New South Wales Archives, Mitchell Library, Queensland State Archives, and a few smaller regional historical libraries and museums. Though some 60 sources were located in this manner, very few detailed 'fortified' structures. Similarly, many collections of early photos of 'pioneer' huts were assessed, though almost none of these images possessed sufficient detail or clarity to allow their features to be assessed.

We defined 'domestic' as any civilian structure used for regular working, cooking, sleeping or relaxing. We eliminated any descriptions that were too generic (e.g. 'every habitation [in the St George area]' or 'almost every homestead on the Belyando') and focused on accounts that referred to a specific pastoral run or structure that could be plotted with some precision. ${ }^{33}$ We researched all identifiable authors, their familiarity with the region, broader knowledge of the topic and their proximity to the source. Thus each account was assessed for its reliability according to the identifiability and credibility of the author and its degree of separation from the original builder, owner, manager or other occupier of the structure. 'First-hand accounts' were therefore defined as those provided by initial builders or inhabitants, or people who visited or knew the place intimately, regardless of when they were written. 'Second-hand accounts' usually derived from children of the original owners/occupiers and were typically recorded at a much later date, when this second generation themselves were classed as 'old pioneers'. 'Third-hand' or further removed accounts denoted stories from grandchildren or subsequent owners and other, later sources, many of which could only be attributed to a generic origin (e.g. 'old timers'). These could only be classified as 'local lore'. We acknowledge that such data are incomplete, given that written sources on frontier violence are often partial. ${ }^{34}$ Moreover, first-hand accounts were rarely contemporaneous, as builders or users were not usually in a position to write reports until decades after. We also acknowledge that many accounts, regardless of their origin, were only published much later as memoirs, leading to the possibility that they could have been edited for content prior to publication, but this is impossible to trace without original, unpublished versions.

33 Balonne Beacon (St George), 20 December 1951, 10; Townsville Daily Bulletin, 14 July 1947, 7.

34 See Foster, “'Don't Mention the War". 


\section{A fortified frontier?}

Our survey generated 125 accounts of 97 different structures across Queensland (Figure 1). The majority of accounts derived from third-hand or further removed sources (64 per cent; $n=78)$, while 22 per cent $(n=28)$ were better-provenanced secondhand accounts (Figure 2$)$. Just 13 per cent $(n=17)$ were first-hand accounts (Table 1$)$.

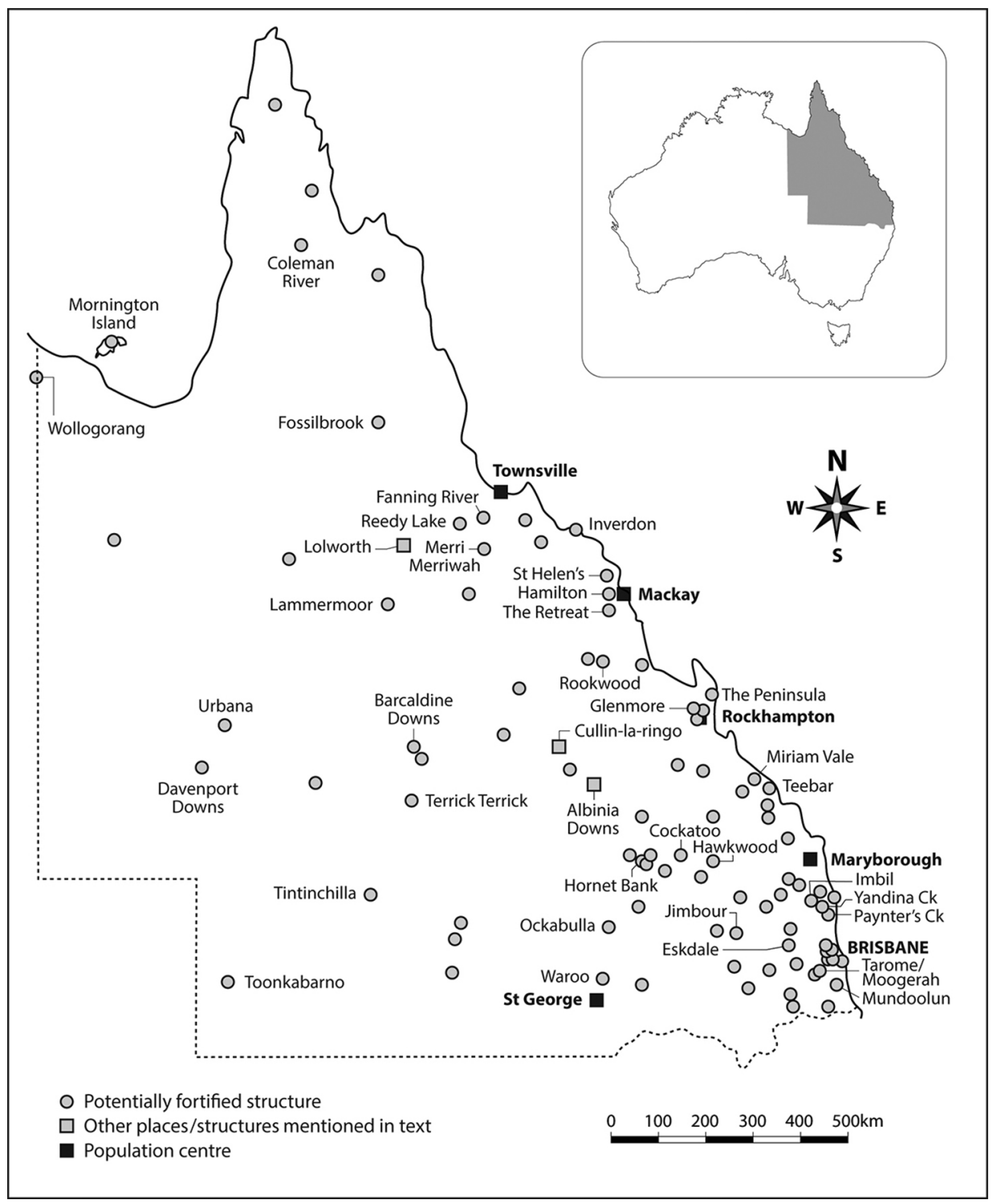

Figure 1: Location of properties with claimed defensive features and main locations mentioned in the text.

Source: Authors' data. 


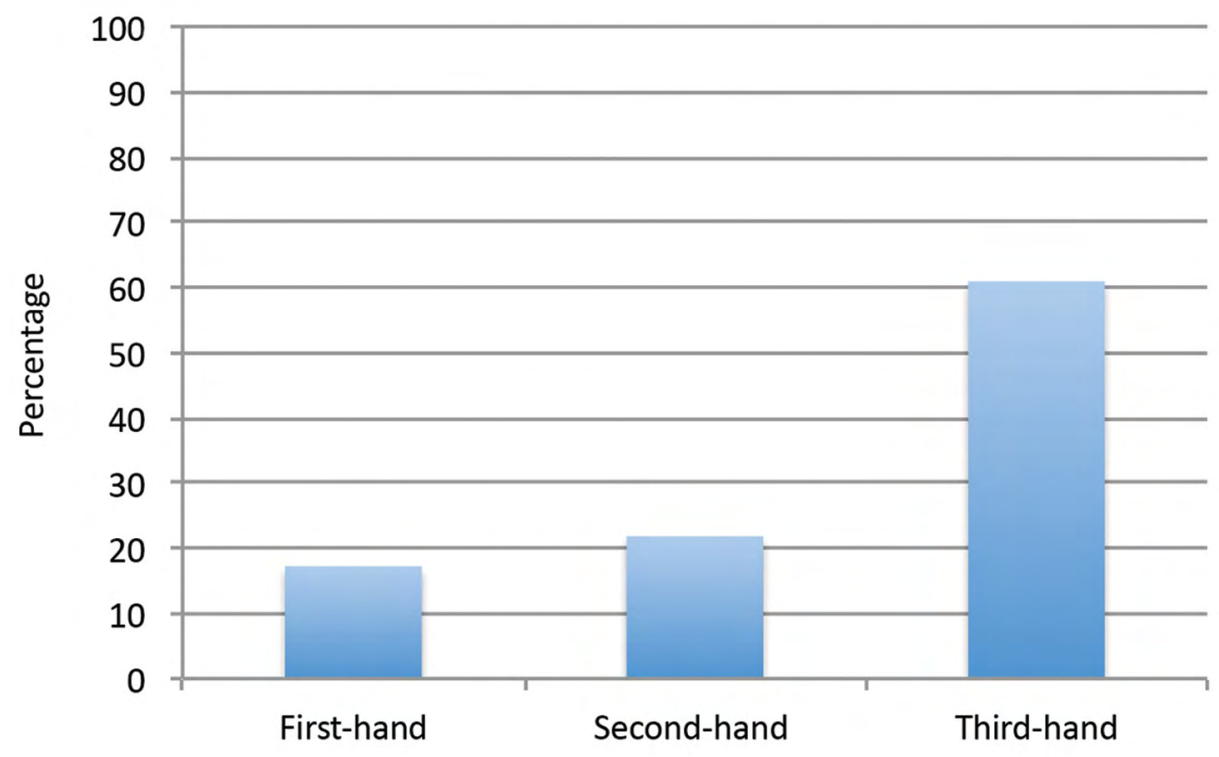

Figure 2: Relative reliability of accounts.

Source: Authors' data.

First-hand descriptions by Ernest Henry (1859), C. S. Rowe (1864) and William Hill (1865) of structures on the Burdekin River, John McCartney of his run near Proserpine (c. 1866), John Carpenter of the Ockabulla run on the Maranoa River (1851) and prospectors on the Coleman River (1878) all refer to buildings they themselves built or inhabited. Henry's description of a stockade built by George Dalrymple's reconnaissance party in 1859 derives from Henry's letters written at the time and is particularly detailed:

We placed four upright poles in the ground enclosing a space about $12 \mathrm{ft}$ by $8 \mathrm{ft}$ then joined them by long saplings passed through the forks at the top, dug a trench about $1 \frac{1 / 2}{\mathrm{ft}}$ deep all round in which we placed saplings leaning a little outwards against those at the top. We then placed all plates against the upright to keep them firm, filled in the trench, first laying poles on either side at the base of the saplings. We then placed two very tall forked poles at either end with a ridge pole across and spread our largest tent over all. Altogether it was very strong and well loop-holed, the walls were 8 or 9 feet high. ${ }^{35}$

35 Ernest Henry, cited in Breslin, Exterminate with Pride, 41. 


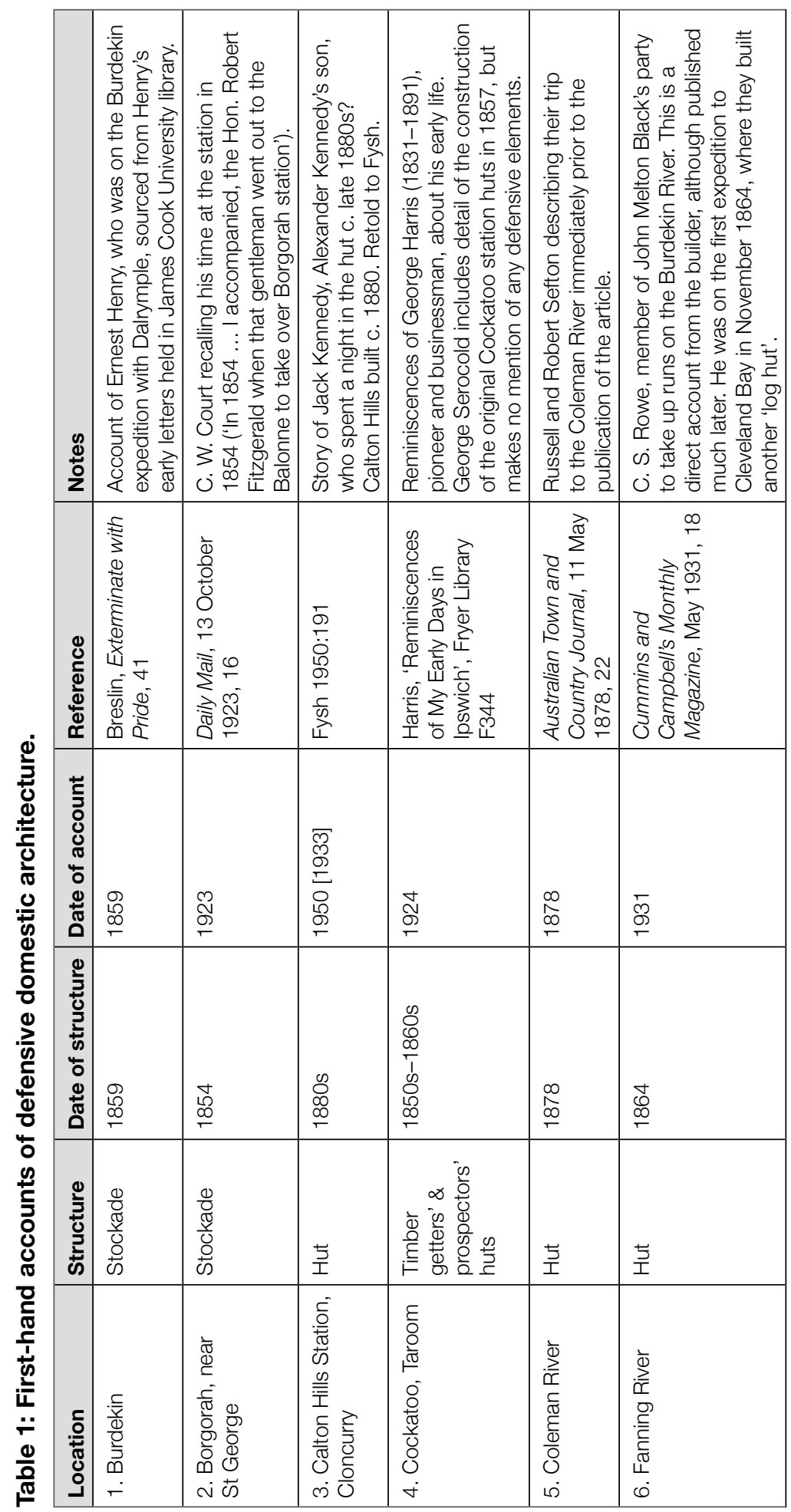


NERVOUS NATION

\begin{tabular}{|c|c|c|c|c|c|c|c|}
\hline $\begin{array}{l}\text { \& } \\
\stackrel{2}{0} \\
z\end{array}$ & 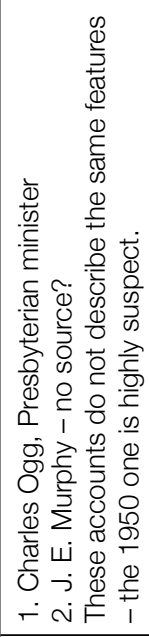 & 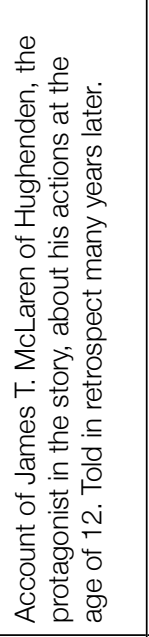 & 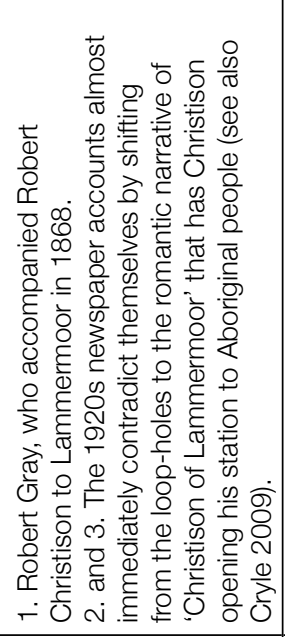 & 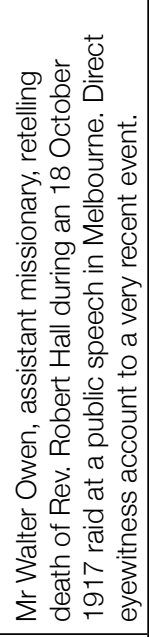 & 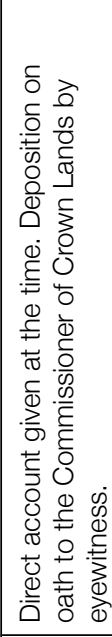 & 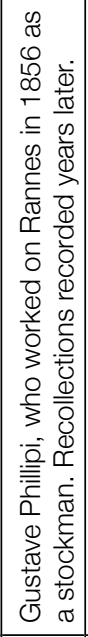 & 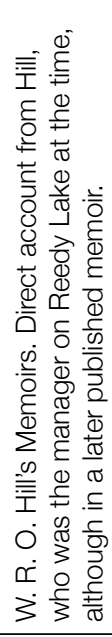 \\
\hline 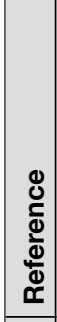 & 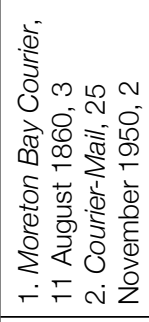 & 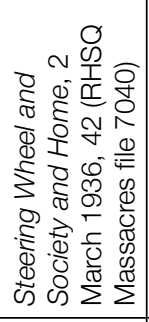 & 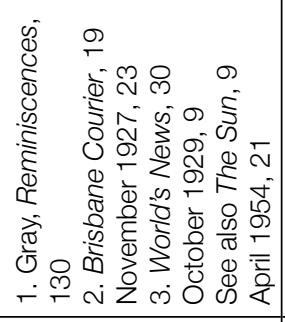 & 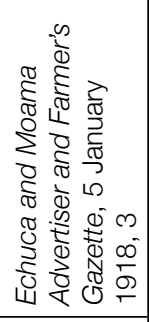 & 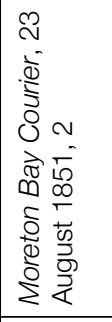 & 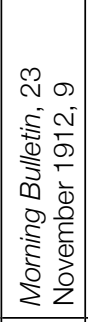 & 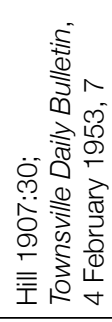 \\
\hline 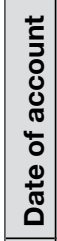 & 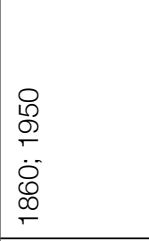 & $\begin{array}{l}0 \\
\stackrel{్}{\sigma} \\
\end{array}$ & 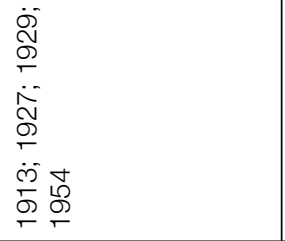 & 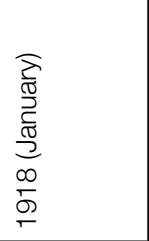 & $\begin{array}{l}5 \\
\infty \\
\infty\end{array}$ & $\frac{N}{\sigma}$ & 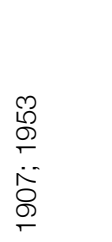 \\
\hline 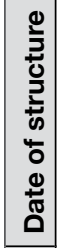 & $\begin{array}{l}8 \\
\bigotimes \\
-\end{array}$ & 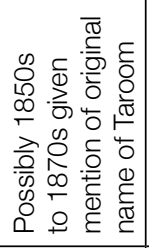 & $\begin{array}{l}\infty \\
0 \\
\infty \\
\Gamma\end{array}$ & $\begin{array}{l}\bar{\sigma} \\
\overline{0} \\
\overline{0} \\
0 \\
0 \\
0 \\
0 \\
0\end{array}$ & \begin{tabular}{|l}
$\bar{L}$ \\
$\infty$ \\
$\Gamma$
\end{tabular} & $\begin{array}{l}0 \\
\infty \\
\infty \\
\Gamma\end{array}$ & $\begin{array}{l}\infty \\
\infty\end{array}$ \\
\hline 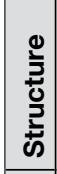 & 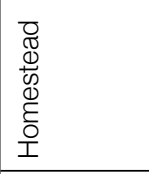 & 고 & 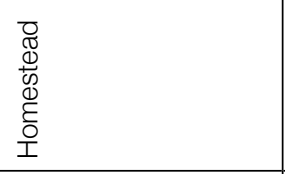 & 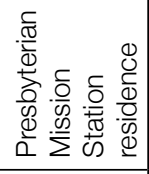 & 蒿 & 포 & 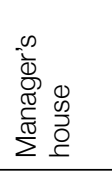 \\
\hline 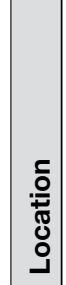 & 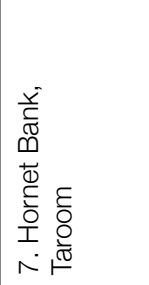 & 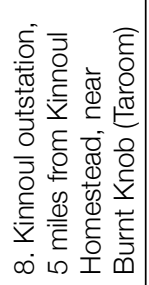 & 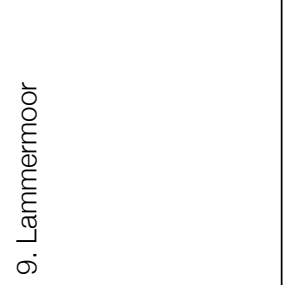 & 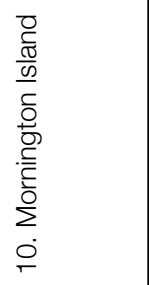 & 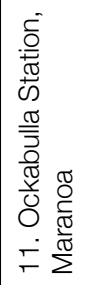 & 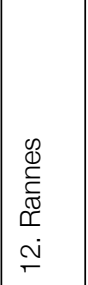 & 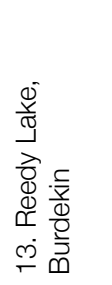 \\
\hline
\end{tabular}




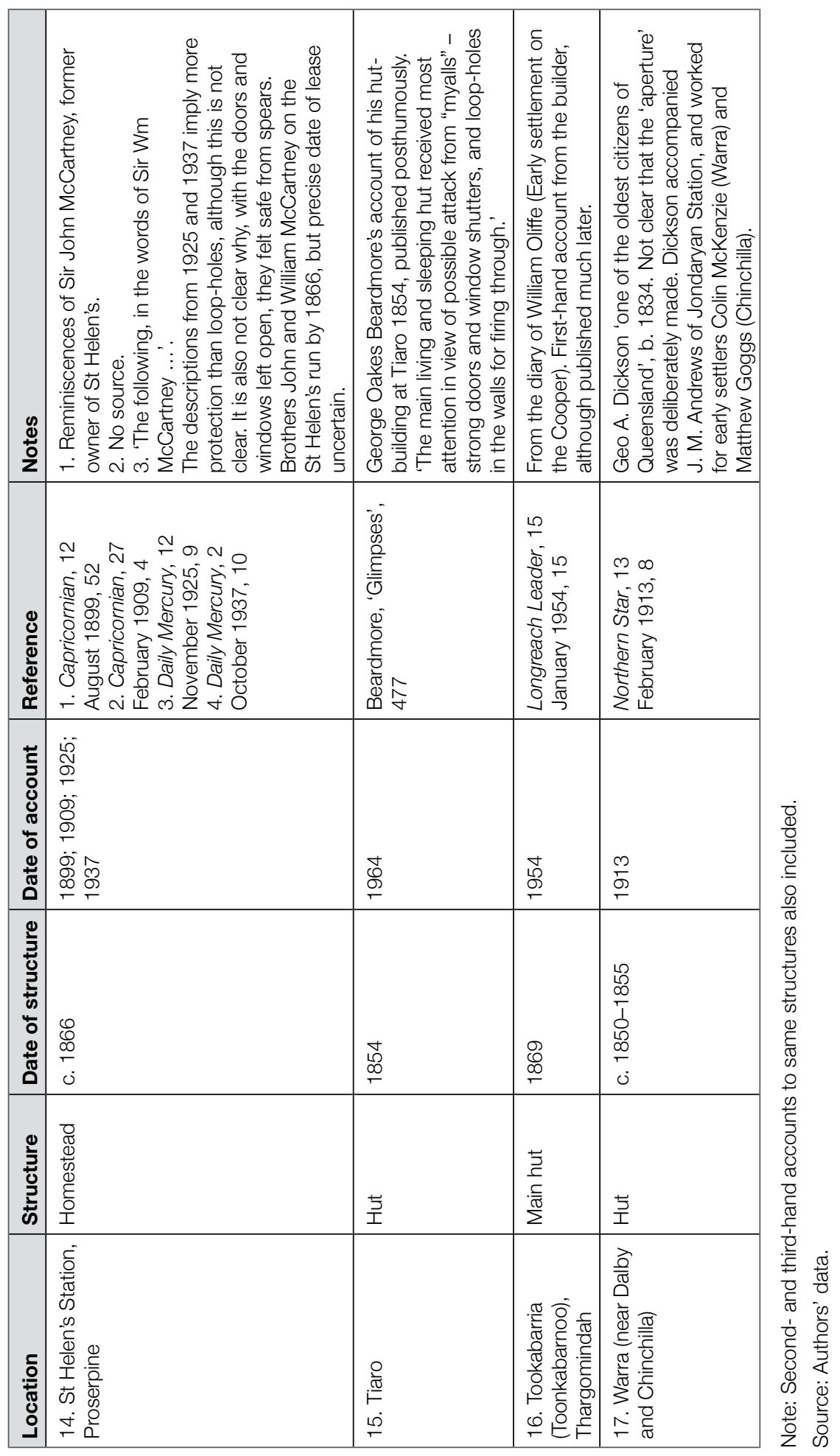


Similarly, John Carpenter's deposition was made to a magistrate when he was a hutkeeper on Ockabulla in 1851. When attacked he:

barricaded the door, opened the port-holes (which are usually made in huts on the frontiers, for the purpose of resisting the assaults of the natives), and laid the fire-arms on the table. From one of the port-holes he saw about five hundred blacks assembled ... They blocked up the port-holes before Carpenter had an opportunity of firing at them, but he stabbed one of them in the eye through a chink beside one of the holes ... some ... climbed on to the roof of the hut, and set fire to the bark roofing. ${ }^{36}$

The 'log hut' erected by a prospecting party to the Coleman River in 1878 was described by its builders only a few months after its construction. ${ }^{37}$ This particular account is further supported by description of a second hut, 'strongly built of squared logs, loopholed and spear-proof', erected by the same party near Coen, that was visited by Robert Logan Jack in 1879 and so has both a first-hand and a second-hand account attached to it. ${ }^{38}$ An account of Lammermoor by Robert Gray in 1868 and another of Hornet Bank by Charles Ogg in 1860 both describe buildings visited not long after their construction or alteration for defensive purposes. The account from Mornington Island in 1918, though relatively late, can also be considered reliable in that it refers to events that took place less than three months before its date of publication. ${ }^{39}$

A second finding is that the structures proposed as being fortified were predominantly homesteads or the main huts on sheep or cattle runs (55 per cent of all accounts), followed by adjacent outbuildings (12 per cent) and outstations (13 per cent). This is not surprising given that nineteenth-century pastoral runs were vast unfenced domains containing large numbers of stock; these, apart from the nuclei of a head station, relied on a network of widely separated outstations to monitor animals, paddocks and water sources. ${ }^{40}$ The latter were usually important resource areas for Aboriginal people, transforming pastoral runs into one of the main arenas for conflict.

\footnotetext{
36 Moreton Bay Courier (Brisbane), 23 August 1851, 2.

37 Australian Town and Country Journal (Sydney), 11 May 1878, 22.

38 Jack, Northmost Australia. This is described as a 'loopholed log hut' in an earlier account by Jack in the Wingham Chronicle and Manning River Observer, 17 June 1916, 7.

39 Echuca and Moama Advertiser and Farmer's Gazette, 5 January 1918, 3.

40 Hodgson, Reminiscences of Australia.
} 


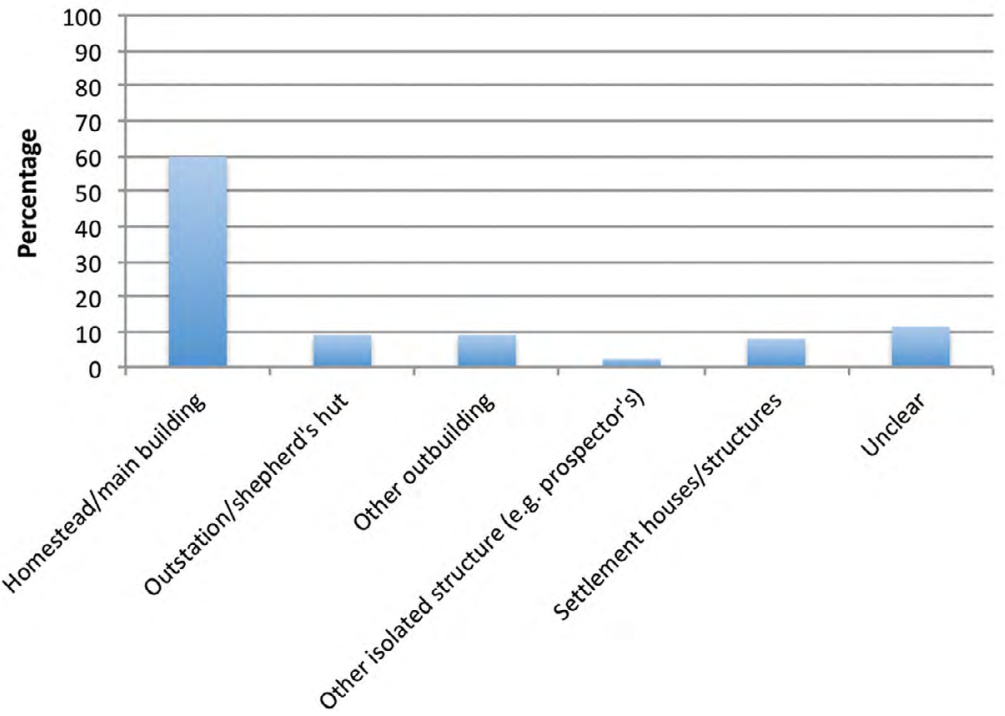

Figure 3: Types of structures with defensive features.

Source: Authors' data.

\section{Potential defensive elements}

We found a relatively restricted range of rather simple features being regularly described as defensive (Table 2). Unfortunately, many accounts lacked precision and provided insufficient detail regarding form, size or placement, or used vague descriptors, such as 'thick walls' or 'heavily built outhouses'.

Table 2: Summary of architectural elements associated with the defence of domestic structures in Queensland.

\begin{tabular}{|l|c|}
\hline Architectural feature/element & Frequency (no. of references) \\
\hline Blockhouses & 4 \\
\hline 'Log' cabins & 3 \\
\hline Loop-holes (including apertures, port-holes, slits and slots) & 84 \\
\hline Barricades (including palisade fencing) & 19 \\
\hline Mud walls or plastering & 3 \\
\hline Stone walls & 6 \\
\hline Commanding position/view & 3 \\
\hline $\begin{array}{l}\text { Other (water tower, refuge room, stockade, dense wire netting } \\
\text { across windows) }\end{array}$ & 8 \\
\hline TOTAL & $\mathbf{1 3 0}$ \\
\hline
\end{tabular}

Note: Some structures possess more than one element.

Source: Authors' analysis. 


\section{Loop-holes}

By far the most commonly described features were 'loop-holes', variously labelled as slots, slits, port-holes, apertures or 'shooting holes'. Some huts were described as entirely windowless except for such apertures, while other references alluded to the use of 'port-holes' as hatches that could be both readily shut or blocked and positions from which to shoot at attackers. ${ }^{41}$ In terms of construction, loop-holes were most often described as cut, bored (e.g. sites at Rookwood, Cockatoo), pierced (e.g. Waroo) or augered through timber slabs (e.g. sites at Imbil, Yandina Creek, Herbert River). All first-hand accounts referred to some version of a loop-hole. Perhaps the best observer among this group was Robert Gray, a member of the 97th Regiment of Foot, who participated in the final siege of Lucknow (British India) in $1858 .{ }^{42}$ In describing Lammermoor Station in north-west Queensland in 1868, built by his friend and neighbour, Robert Christison, Gray noted: 'My friend had then a substantial and neatly erected log hut with loopholes for rifles' ${ }^{43}$ Owing to his prior military experience, Gray could be expected to know a functioning loop-hole when he saw one.

In terms of the form a loop-hole took, most accounts implied round holes, especially those that described them as having been augered. The description of Yandina Station on the Sunshine Coast, for example, referred to 'three inch $[7.5 \mathrm{~cm}]$ auger holes' ${ }^{44}$ Descriptions of the Miriam Vale, Tintinchilla and Retreat Stations included square holes, and one account referred to vertical slits or slots (at Jimbour, near Dalby). ${ }^{45}$ Another (referring either to Urbana Station, near Jericho, or Mexico Station on the Diamantina River) described a small window, 1 foot (approximately $30 \mathrm{~cm}$ ) square and elevated 5 feet $(1.5 \mathrm{~m})$ above the ground built into each wall, while a secondhand account of the homestead on the Tarome and Moogerah runs near Warwick described 'three auger holes breast high in each slab'. ${ }^{46}$

A second-hand account of Retreat Station near Mackay, referring to c. 1860, described loop-holes positioned strategically at the corners of a hut:

at each corner, there was a sort of square, port hole cut just big enough to sight a gun. There were twelve of these holes in this hut, and a gun and ammunition hanging up alongside each one. ${ }^{47}$

\footnotetext{
41 Queenslander (Brisbane), 19 December 1885, 5; Capricornian (Rockhampton), 27 February 1909, 43.

42 Gray, Reminiscences of India and North Queensland, 22.

43 Gray, Reminiscences of India and North Queensland, 130.

44 Bull, Short Cut to Gympie Gold, 64-65; Andison to Fred Fink, 1997, Fred Fink Collection, Sunshine Coast Council Heritage Library.

45 Central Queensland Herald (Rockhampton), 8 September 1949, 3; Warwick Daily News, 20 February 1937, 8; Moore, 'Restraining Their Savage Propensities', 91.

46 Brisbane Courier, 5 May 1933, 14.

47 Daily Mercury (Mackay), 21 June 1928, 5.
} 
Corner placement is a particularly effective tactic, as demonstrated by the late nineteenth-century Cape York telegraph stations:

at each corner of the houses small rooms about $4 \mathrm{ft}$. or $5 \mathrm{ft}$. square will be provided in which, if at any time the building were attacked by blacks, the inmates could secrete themselves, and through loopholes provided for the purpose, fire upon the enemy. The rooms and loopholes are to be arranged so as to enable the marksmen to cover a very large area of ground on each side of the angle. ${ }^{48}$

A slab hut on Hawkwood Station in the Burnett District (c.1850s-1860s), allegedly went a step further:

there were slots cut in the slab walls through which aperture a rifle could be used for protecting the inhabitants from the wild blacks. When the rifle was withdrawn a piece of iron would drop across the hole on the inside so that spears thrown at the hut could not find a way through these apertures. ${ }^{49}$

Two unreliable local lore accounts specified loop-holes positioned at different heights. One (at Hamilton, near Mackay, built c. 1863), claimed that the upper was specifically for viewing and the lower 'to protrude the barrel of a gun in an attack' ${ }^{50}$ The second (Teebar homestead), published as part of an obituary for Elizabeth Thomas, daughter of John Eaton, who took up Teebar from Henry Cox Corfield in 1856, alleged sets of 'slanting' holes 'cut low down in the walls, to enable those inside to send a raking cross fire'. ${ }^{51}$ There are various issues with the vagueness of this description, including what is meant by 'slanting', the height relationship between the two sets of holes, and the limitations of older muzzle-loading weapons - the relative slowness of which would have prevented anything approaching a 'raking cross fire'. However, it was standard practice to fire from shoulder height and shooters often preferred elevated holes (which they accessed by standing on boxes), to allow better vantage. ${ }^{52}$

Small round holes in the walls of a hut are less likely to function successfully as defensive elements for a number of reasons. First, a single hole by itself is ineffective, since it provides no means for the occupant to simultaneously shoot and be able to view the threat. Two settlers, George Harris and Thomas Welsby, recalled that small holes were generally bored as 'peep holes' for surveillance rather than shooting, which suggests many of these openings have been misidentified. ${ }^{53}$ Some accounts refer to

48 Queenslander (Brisbane), 30 January 1886, 165.

49 Bloxsome, 'Discovery, Exploration and Early Settlement of the Upper Burnett', 344.

50 Manning, In Their Own Hands, 90.

51 Maryborough Chronicle, Wide Bay and Burnett Advertiser, 24 November 1933, 6.

52 Rod Pratt, email communication to Ray Kerkhove, 9 April 2019.

53 Harris, 'Reminiscences of My Early Days in Ipswich', Fryer Library, F344; Courier-Mail (Brisbane), 18 February 1939, 7 . 
the expedient use of gaps between slabs for surveillance purposes (e.g. Maryvale, near Warwick). Second, they would need to be angled outwards in order to be effective, and even then their field of fire would have been relatively limited.

One defensive advantage ofloop-holes was that they could be created opportunistically. A first-hand account from Mornington Island described cutting 'loop holes in the galvanised iron walls ... with a tin-opener', while another first-hand account from far north Queensland described augering convenient holes in the timber floorboards of a high-set building during an event. ${ }^{54}$ Likewise George Harris's account claimed 'peep holes' were enlarged for shooting only if the need arose. ${ }^{55}$

\section{Blockhouses and log cabins}

Although mentioned more rarely, another architectural reference is to 'blockhouses' and/or 'log cabins'. A blockhouse is an overtly militaristic feature, built either inside a fort or occupying a defensive position of its own. In the United States in the eighteenth century they were typically cantilevered, with an upper floor projecting outwards above the lower, loop-holes provided around the circumference on both storeys, and sometimes hatches in the upper-storey floor. ${ }^{56}$ Two storey blockhouses are also found in New Zealand and include features such as milled timber walls and double exterior walling filled with gravel, clay or other protection against gunfire, and were often built with palisades or other external physical barriers. ${ }^{57}$ None of the Queensland descriptions featured two storey buildings with cantilevering, wall filling or external palisades, although most accounts were too imprecise to determine how the structures were built. ${ }^{58}$ The term was also often used to describe timber slab construction, which was, by its nature, quite solid (e.g. a 'slab-walled blockhouse kitchen'), and sometimes the terms 'stockade' and 'blockhouse' were used interchangeably. ${ }^{59}$ None of the accounts referred to milled timber buildings. Chronologically, the term 'blockhouse' only arose in twentieth-century accounts, the earliest of which dates from 1935. This suggests that the term is a retrospective designation used generically rather than a description of a specific, recognised structural form. Its use should therefore be treated with caution.

\footnotetext{
54 Echuca and Moama Advertiser and Farmer's Gazette, 5 January 1918, 3; Nahrung, Life of Konrad Nahrung, 44-45.

55 Harris, 'Reminiscences', Fryer Library, F344.

56 See, for example, Carlisle, 'Notes on the Architecture of Fort McIntosh'; Mann et al., 'From Blockhouse to Hog House'; Prickett, 'The Archaeology of the New Zealand Wars', 9.

57 Prickett, 'The Archaeology of the New Zealand Wars'; Walton, New Zealand Redoubts, Stockades and Blockhouses. 58 See, for example, Linn, 'An American Treasure in Fairbanks'; and examples in Prickett, 'The Archaeology of the New Zealand Wars', and Prickett and McGovern-Wilson, Planning a Future for New Zealand War Sites and Landscapes, which are all single storey timber structures, although still unusually built.

59 Hain and Searight Pty Ltd, 'The History of Kilkivan', 6.
} 
One structure described as a blockhouse - Glenmore, built near Rockhampton in 1858 - has been described as such since 1935 . However, this more accurately describes its $\log$ cabin style of construction rather than its form per se (Figure 4). The State Heritage listing for the property (Place ID 600823) describes it as 'a one room hut built of horizontal logs checked into each other at the corners and lined with bark'. ${ }^{60}$ A second structure, built in 1864 at Fanning River inland from Townsville, also employed notched-corner log cabin construction, in this case in accordance with New Zealand practice. A direct account by C. S. Rowe, one of the builders and a member of John Melton Black's party to take up runs at Fanning River, claimed that:

All hands set to work to cut timber for building a log hut. The architect and moving spirit was Joe Dunn. He had seen how things were done in New Zealand. Huge logs, dove-tailed at the corners, were rolled up on skids. With holes cut here and there for our rifles, they afforded a valuable protection. It afterwards turned out that our precautions were hardly necessary. We never saw a black about the station for twelve months. The hut, however, lasted for many years. ${ }^{61}$

A later visitor to the run described the building in 1880 as 'long and roomy, built of round $\operatorname{logs}$ and roofed with ironbark'. ${ }^{62}$

Miles Lewis has noted the confusing tendency in nineteenth- and twentieth-century literature to mislabel slab buildings as 'log' huts, but these latter descriptions are clearly referring to a genuine form of $\log$ construction. ${ }^{63}$ Lewis noted that both palisaded poles set into a trench with horizontally or vertically framed logs, and the more iconic US notched-corner style were common across Australia. Although the $\log$ cabin style was more unusual in the tropical north, similar log cabins were built at Merri Merriwah (Figure 5) and Reedy Lake, both on the Burdekin River, at about the same time as the 1864 Fanning River structure. ${ }^{64}$ Reedy Lake was also claimed by its first inhabitant, William Hill, to have been built defensively, albeit for the loop-holes it included rather than its construction technique. ${ }^{65}$ Charles Eden noted of Merri Merriwah that ' $[t]$ he house, in place of the usual slabs, was built of whole she-oak trees, plenty of which grew in the creek adjoining', but did not claim this to be defensive. ${ }^{66}$

\footnotetext{
60 See also Miles Lewis, '2.02 Logs', Australian Building: A Cultural Investigation, 31, accessed 19 July 2019, mileslewis.net/australian-building/.

61 Cummins and Campbell's Monthly Magazine (Townsville), May 1931, 18.

62 Stevenson, Seven Years in the Australian Bush, 29-30.

63 Lewis, '2.02 Logs'.

64 Allingham, Taming the Wilderness, 71; Bell, 'TFTA Fanning Sectors'.

65 Hill, Forty-five Years' Experience in North Queensland, 30.

66 Eden, My Wife and I in Queensland, 134.
} 

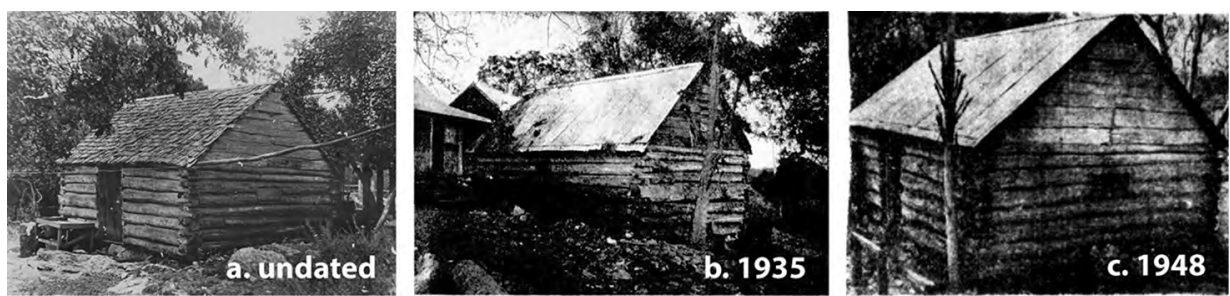

Figure 4: Glenmore 'blockhouse': a) ‘McCartney’s Hut at old Glenmore', undated (SLQ Image 14057); b) “"Stockade” built by J.A. McCartney in 1857 on Glenmore'; c) 'Glenmore blockhouse'.

Sources: a) Courtesy of State Library of Queensland; b) Central Queensland Herald, 28 March 1935, 5; c) Morning Bulletin, 25 August 1948, 3.

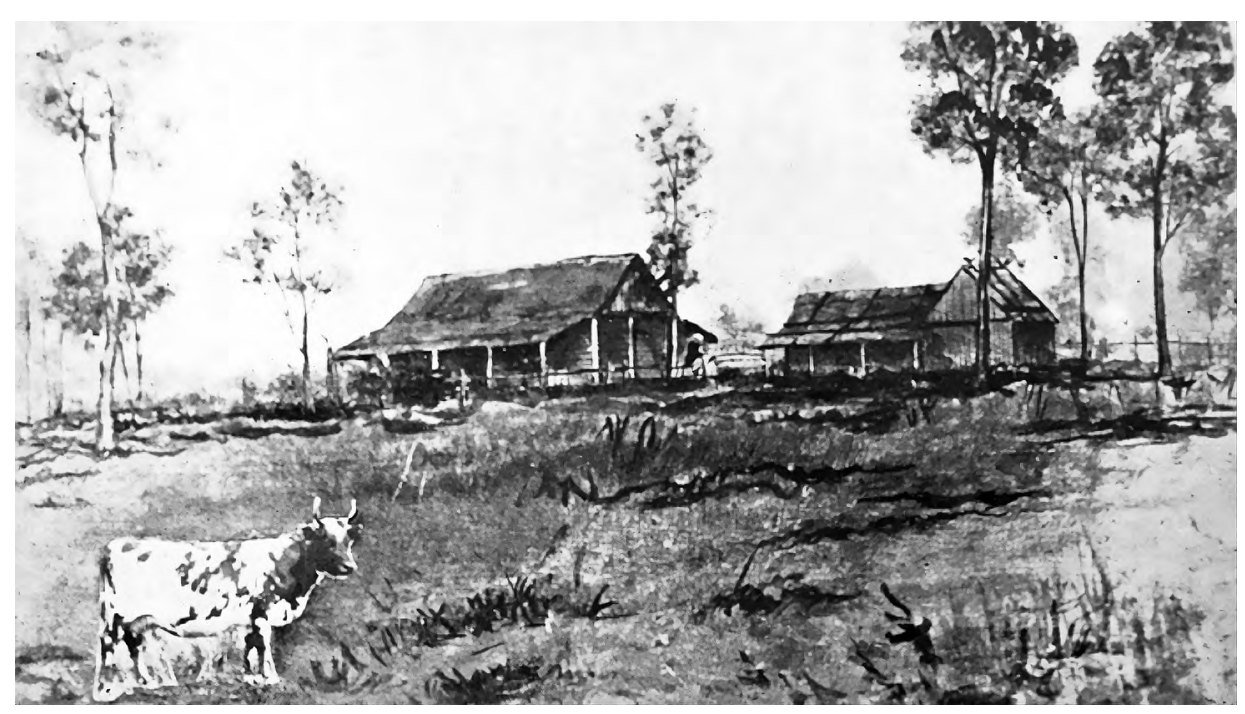

Figure 5: Undated sketch of Merri Merriwah Station.

Source: Jane Black, North Queensland Pioneers (Charters Towers: Queensland Country Women's Association, 1930), 26.

\section{Other structural features}

Our survey noted claims for several other defensive features, including small, highset windows (Knockbreak, near Gayndah [second-hand account]), wooden shutters and doors that could be bolted (Davenport Downs, Fossilbrook and Barcaldine Downs [first-hand and third-hand]), bars or dense wire netting across windows and chimneys (Wollogorang, Fossilbrook, Mundoolun and Belyando [second-hand and third-hand]), a refuge room (Paynter's Creek [second-hand]), external fencing (Burgorah, near St George [first-hand], Inverdon and Sweer's Island [second-hand]) and elevation (The Peninsula [third-hand]). 
Wooden shutters were ubiquitous on early buildings because glass was expensive and difficult to acquire, and the only other option was an uncovered opening, although being able to close and strongly secure openings provided obvious defensive benefits. At Albinia Downs, Robert Patton noted that the Dutton family always secured the house at night, a situation that was only ameliorated by the arrival of the Native Mounted Police in $1860 .{ }^{67}$ Others were less circumspect. Describing the hut he inhabited on St Helen's Station near Proserpine c. 1866, John McCartney noted that, although the hut was loop-holed 'we did not bother to close the doors or shutters, knowing we were safe from spears' ${ }^{68}$

An external palisade (or 'stockade') was mentioned in several accounts, although only Dalrymple's structure on the Burdekin, referred to previously, provided details of form. C. W. Court, who accompanied Robert Fitzgerald when he took over Burgorah Station near St George in 1854, for example, recalled in 1923 how:

it was absolutely necessary, after dark, to be within the precincts of the stockade which was erected around the homestead. We mounted no cannon, and did not even possess a 'Brown Bess,' but there were four old blunder busses, fired by flints, stationed at each corner, and it was our usual custom, after having first loaded them with gravel, to fire one occasionally at sun down, just as a warning. ${ }^{69}$

On Sweer's Island, a second-hand account by a visitor from Normanton in 1883 described preparations that also included protecting the domestic water source:

Here we found a large bouse strongly palisaded, and having wooden defence works. The house was occupied by one man, his wife, and family. We were informed that the palisades had been erected as a protection from the blacks who dwell on the neighbouring Islands, and that every member of the household could use the rifle ... A well was sunk within the enclosure, and a pump had been fixed upon a high stage. From this pump wooden troughing or guttering had been laid to the beach, and it was there that vessels obtained water. ${ }^{70}$

\section{Remembering the frontier}

Another approach to this body of data is to analyse how it was assembled over time, and the implications of the circulation of such accounts for the construction of a broader settler colonial narrative. Although the structures were built between the 1840 s and the 1890s, the stories related to them were published between 1851

67 Sydney Morning Herald, 1 December 1862, 2.

68 Capricornian (Rockhampton), 27 February 1909, 4.

69 Daily Mail (Brisbane), 13 October 1923, 16.

70 Maryborough Chronicle, Wide Bay and Burnett Advertiser, 30 December 1901, 3. 
and 2019, with the majority clustering between the 1910s and the 1950s (Figure 6). The hiatus between the construction of a building and the telling of a fortification story relating to it ranges from no delay to over a century.

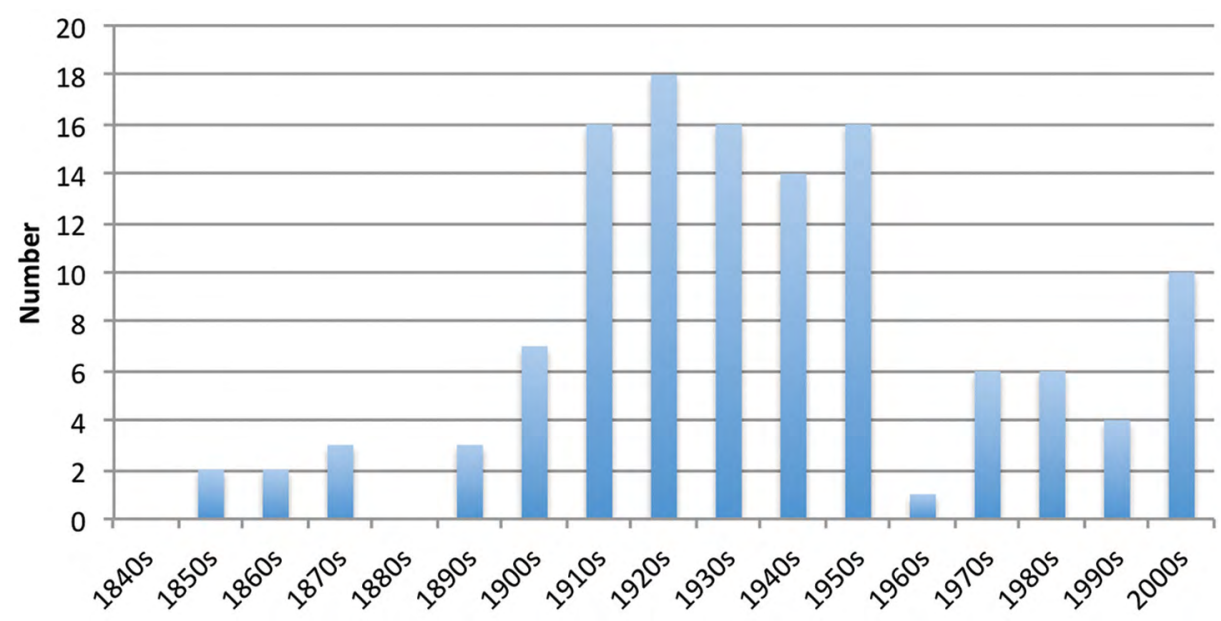

Figure 6: Distribution of accounts across time.

Source: Authors' data.

Fortification narratives began notably to rise in the first decade of the 1900s. As much of Queensland was settled during the 1840s-1870s, this partly reflects the fact that many of the original hut builders were then in old-age, with enough time (and suitable public interest) to offer a fuller account of their lives. By this point their experiences were considered intriguing, as the conditions they experienced were no longer normative. However, this rise also dovetails with the development, over the following three decades, of the classic pioneer tale: a knitting together of individual, family and regional histories into a narrative of achievement and attainment that exemplified the progress of Queensland as a colony and a state. Building on earlier imagined foundations represented in image (Figures 7 and 8) and word (e.g. John Farrell's 1901 poem, 'The Last Bullet'), such accounts perpetuated a disruptive racial inversion by repositioning Aboriginal people as the raiders of European territory:

Indigenous people are seen as entering the settler space (and disturbing an otherwise serene unperturbed circumstance) after the beginning of the colonisation process ... Settler colonial narratives, of course ... celebrate violence against Indigenous people, but always as a defensive battle ensuring the continued survival of the settler community and never as founding violence per se. ${ }^{71}$

71 Veracini, 'Settler Collective, Founding Violence and Disavowal', 366, 371, italics in original. 


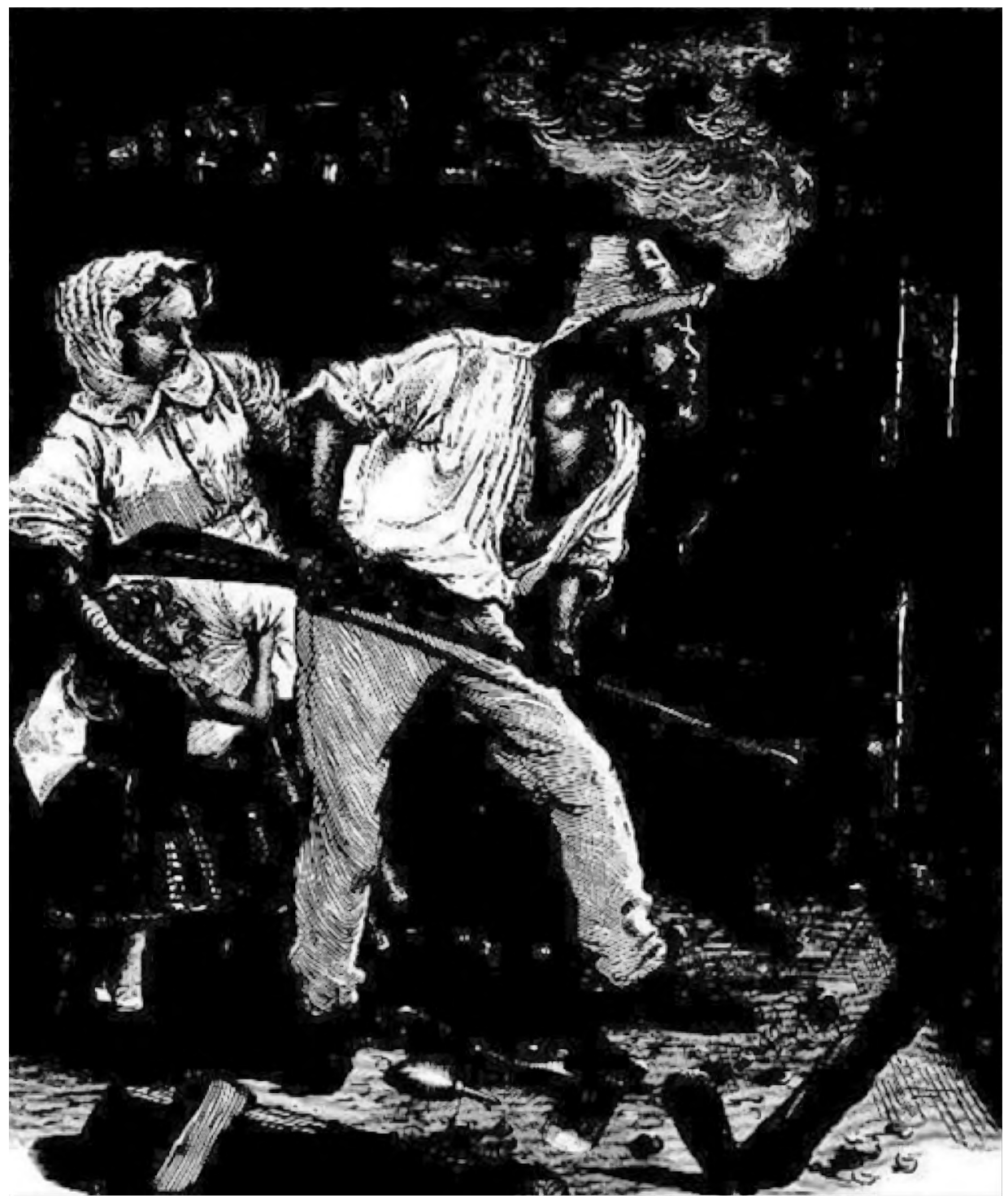

Figure 7: The ultimate moment of settler defence: 'Besieged by Blacks'. Source: Australasian Sketcher with Pen and Pencil (Melbourne), 21 March 1874, 215. 


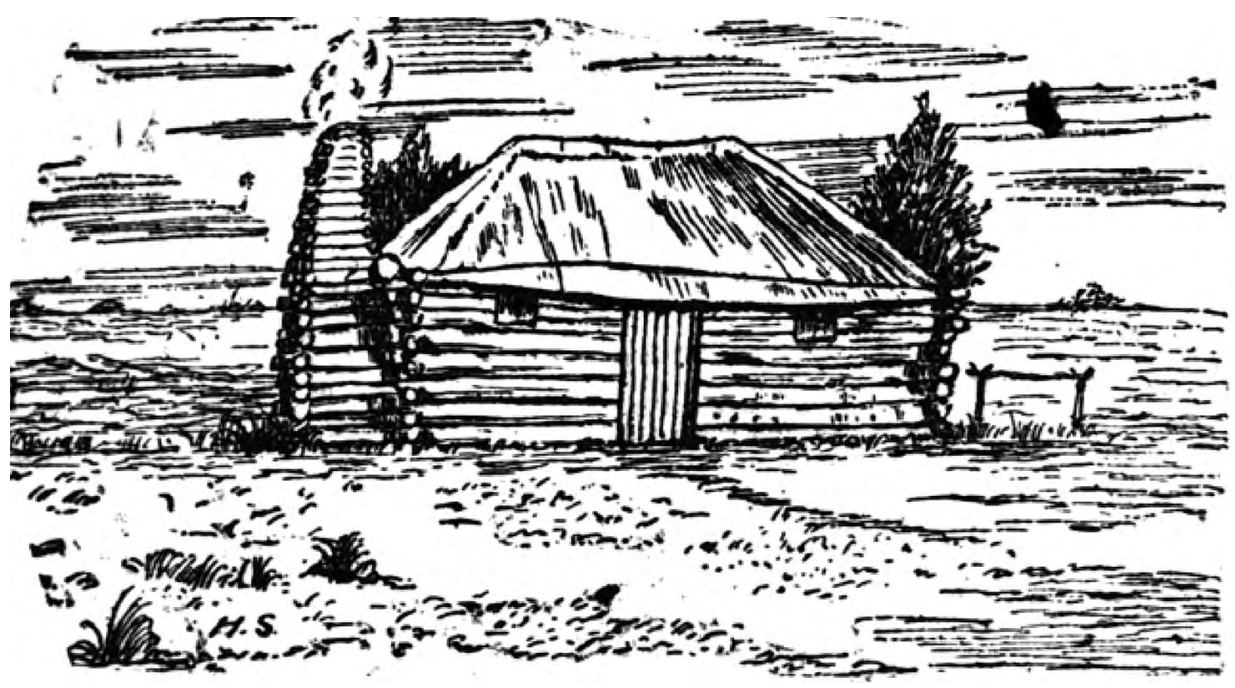

Figure 8: An apocryphal 'Queensland outstation' with classic defensive features of notched-corner log construction and small, high-set windows.

Source: Evening News (Sydney), 5 February 1898, 2.

The popularity of fortification narratives was strengthened in the 1920s and 1930s by the progress of Australian nationalism in the aftermath of the First World War. Political tussles during these decades were informed by the British imperialism of the right-wing parties, and the more self-reliant and less British-focused form of nationalism preferred by the left. ${ }^{72}$ The pioneers constituted one pillar of the left's 'true Australianness', interwoven at the local level with attempts to secure the tenure of white occupation within particular regions. ${ }^{73}$ Consequently, nostalgia coloured these interpretations, as illustrated by Andrew Crombie in the 1920s when mourning the loss of the fortified homestead at Terrick Terrick:

In coming years, and in the face of modern improvements, the old log hut gradually lost status. From Government House it became the store, later it was the meat house, and next the old building was converted into a fowl house on a magnificent scale. Some years after this I visited Terrick, and found, to my great regret, that the old log hut, which was as strong and durable as ever, had been razed to the ground, carted to the wood heap, and then burnt up for fuel. The manager, a very good fellow, was absolutely devoid of sentiment in connection with pioneers and their great achievements. And so this monument of successful pioneering disappeared in smoke. ${ }^{74}$

72 Dryenfurth, 'Labor and the Anzac Legend'.

73 Kirk, “'Australians for Australia”, 101.

74 Queenslander (Brisbane), 12 September 1925, 11. 
Fox's 1919 three-volume History of Queensland canonised the nostalgic pioneer story and its sacred elements, constructed as it was from interviews with hundreds of multi-generational pastoral families. ${ }^{75}$ Exhibiting all of the features of Slotkin's frontier mythos, History of Queensland codified familial memories around repeated elements: the ever-present threat of hostile natives, the perils of environment, climate and distance, the values of perseverance and endurance, and the goal of 'building up ... a home for himself and future generations of his name - and by the service rendered to the nation in the opening up of the country. ${ }^{76}$ Many of these stories were being told by the second generation and so had already passed into family lore. The frequency of repetition of the trope throughout Fox's three volumes reveals the emergence of a narrative that became common across most of the twentieth century.

A second spike in fortification narratives took place in the 1950s. The relative prominence of such narratives in newspapers and local histories during this decade can be set against the wider, national historiographical trend to muffle the history of Aboriginal Australia. ${ }^{77}$ In other words, while general histories tended to overlook conflict between Aboriginal and non-Aboriginal people, local histories continued to be constructed in relation to it, creating what Nettelbeck and Foster have termed 'a more discomforting relationship between European settlement and Aboriginal dispossession' ${ }^{78}$ Australia in the post-Second World War era embraced modernity, affecting technology, transportation, communications and architecture alike. The social and cultural changes this brought paradoxically also created a nostalgia for what was perceived to be an idealised, 'authentic' and fast-vanishing past, a development that Kerr linked to a burgeoning domestic travel industry connected to high rates of Australian motor car ownership. ${ }^{79}$ John Murphy's Imagining the Fifties sheds light on an underlying gender current of this decade that married aggressive with domestic definitions of masculinity to create the image of men as the ultimate protectors, 'prepared to defend their families, their homes and their country'. ${ }^{80}$ Such sentiments painted well onto a dangerous imagined historical frontier.

Further recirculation of such stories in the 1970 s coincided with a shift in interest from the pioneer narratives of resourceful forebears to the first mainstream historical arguments for frontier violence as an unacknowledged component of Australian local and national history. The 1988 Bicentenary provided an obvious focus for documenting these components, and a 'priority of violence and drama' became

\footnotetext{
75 Fox, The History of Queensland.

76 Fox, The History of Queensland, Volume 1, 308-9; Slotkin, Gunfighter Nation.

77 Broome, 'Historians, Aborigines and Australia'; Curthoys, 'Expulsion, Exodus and Exile in White Australian Historical Mythology'.

78 Nettelbeck and Foster, 'Commemorating Foundation', 53.14.

79 Kerr, 'Through the Rear View Mirror'; see Greenwood, 'Driving through History', for the origins of this phenomenon in the 1920s and 1930s.

80 Murphy, Imagining the Fifties, 40.
} 
central to the construction of many local histories. ${ }^{81}$ Many such histories co-opted claims for both fortified structures and massacres into their narratives as evidence of Aboriginal resistance, even though fortification tales were birthed by earlier strands of local history making and an admiration for white settlement that ran counter to stories of massacres.

Finally, the resurgence of interest in the subject generated by the 'History Wars' in the early 2000s gave a new lease of life to fortification accounts. As Ryan has pointed out, rather than heralding an end to the discussion of violence, the debate this engendered between historians initiated an era of closely detailed local studies that have 'transformed massacres into a subject of study in their own right'. ${ }^{82}$

\section{Fortifying the frontier}

Several insights arise from this synthesis. First, the current study supports to some extent the likelihood that domestic structures across Queensland included defensive features, and that this may have been widespread both geographically and chronologically. The defensive features associated with these structures were minimal, however - holes in walls, and barrable doors, windows or other entry ports - reflecting the often expedient and simple nature of the structures themselves. We found that at least some first-hand, reliable accounts of these buildings and their elements as being defensive exist - even if rare - and their presence alone indicates that incorporating defensive elements into buildings was not unknown. Although this was a behaviour that was rarely recorded by primary witnesses in the Queensland context, it is possible, given the nature and extent of settler fear and anxiety in the nineteenth century, that it was more common than we can now reconstruct. This suggests that settlers on the outer edge of any given frontier may well have viewed themselves (wrongly or rightly) as potentially embroiled in the 'front line' of the frontier wars. This means we agree with Clements and Gregg that settler fear was sufficiently widespread along the frontier that it may have provided motivation for creating crude or complex 'fortification'. This was probably more pronounced in the wake of specific events, especially pivotal attacks on European settlers. The best example is the widespread panic following the killing of 11 members of the Fraser family party at Hornet Bank in 1857 and 19 members of the Wills family party at Cullin-la-ringo in 1861. It is possible that architectural modifications were made in this context to enhance existing, or introduce new, defensive elements. Charles Ogg, a Presbyterian minister who travelled widely throughout the colony in the 1850s and 1860s, for example, described defensive alterations made to the original Hornet Bank homestead in the aftermath of the Fraser deaths:

81 Roberts, 'Bell Falls Massacre and Bathurst's History of Violence', 628.

82 Ryan, 'Untangling Aboriginal Resistance and the Settler Punitive Expedition', 258. 
We found the place well supplied with arms, and all about with their pistols in their belts. There was no window, or, what had been once a window, was now boarded up, with bars across inside and out. The chimney had bars placed across it also in various ways to prevent ingress in that way. On the door post as I entered was still to be seen the blood of victims who had perished in a former attack upon the station. At sundown the place was closed up, and the doors fastened by two heavy bars right across them. It was under these circumstances that I held the first service at the station. On retiring at night each bed room door was again barred off the sitting room, and each apartment well supplied with arms. There was a small port hole in my bedroom, which I was shewn how to open in case of attack. My arms consisted of a double-barrelled rifle which stood at the head of the bed; a large pistol hanging on one of the bed posts, and two more hung by the mirror, besides a sword and dagger, whose edges I looked at and saw that they were intended for keen work. ${ }^{83}$

Moreover, fear enveloped the entire district, as local squatters and their employees waged a prolonged and concerted campaign of death and displacement against Aboriginal people. ${ }^{84}$ Squatters such as George Pearce Serocold, of nearby Cockatoo Station, noted:

There is now war to the knife, and we are not without apprehensions of our head station being attacked at night - large pillars of smoke are being sent up all round to the West and to the North - being signals from one camp to the other - Your pistols have become my daily companions - and we are well prepared whenever they come. ${ }^{85}$

In the 1940s, to mark the centenary of St George, Ellen Meacle retold her girlhood experience of this paranoia in what is now St George, fully 320 kilometres distant from the massacre:

just at sunset, a sweating stockman, on a nearly spent horse, reached the homestead at Mt Driven, bringing the news which he had received from another rider, and which was to be relayed on through the district of the murder of the Frazer family by the blacks, at Hornet Bank ... [This news] was held to be of sufficient importance to warrant the prompt issue of a warning, by relay riders, over several hundred miles of country. Every aborigine, even the friendliest, was [now] suspect; every habitation a miniature fort with loopholed walls and heavily-shuttered windows; every kitchen cupboard ... a small arsenal. ${ }^{86}$

83 Moreton Bay Courier (Brisbane), 11 August 1860, 3.

84 Reid, 'A Nest of Hornets'.

85 George Pearce Serocold to Charles Serocold, 3 March 1858, Tennant Estate Papers, D/D T 2974/7, West Glamorgan Archive Service.

86 Daily Mail (Brisbane), 20 July 1926, 17. 
Second, a cluster of notched-corner log cabins in the mid-1860s around the Burdekin River (at Reedy Lake, Merri Merriwah and Fanning River) tantalisingly suggests that there may have been some regional trends in defensive architecture, although stylistic and pragmatic considerations can also explain such differences.

Finally, the majority of accounts considered here were second-hand or further removed, many of which had a specific context of remembrance that calls their validity into question. These reminiscences, told in hindsight by later descendants, are likely to be thus in many cases inflated - perhaps influenced by the 'pioneer narratives' described above. The embroidering of domestic defence into later personal, familial and regional narratives, while rendering tales of particular buildings suspect, is nonetheless itself something that needs to be considered in its own right. In this sense they fortify the frontier in another way: as touchstones for wider contexts of remembering and forgetting.

\section{Nervous nation}

Disavowal of all founding violence, however, cannot allay anxiety. Notwithstanding obsessively repeated representations of 'quiet country' and 'peaceful settlement', the settler fears revenge. ${ }^{87}$

The variety of accounts of potentially fortified domestic structures collected for this article betray a nervousness among the residents of the frontier - especially those who were most vulnerable personally or situationally - that might not have been universal, but was certainly widespread, pointed and genuine. In this respect, domestic fortifications of the frontier are highly significant for Australian architectural history. Although they were humble structures, they were in part psychological attempts to exert control over fear and anxiety, even if settler belief in the hostility of Aboriginal people represented 'typical attitudes in contemporary colonial society [rather] than a response to the situation at hand' ${ }^{88}$ In other words, many of those who subscribed to general nineteenth-century polemics about Aboriginal people were more prone to presume hostility even in the absence of it, and accordingly exaggerated the 'savage' propensities of Aboriginal people. Such presumptions could quickly lead to offensive actions, such as taking possession of canoes and weapons, or destroying camps, weapons or other objects that in turn propagated actual hostile responses and reified the fear. In the presumption of hostility, it is also possible that some architectural features may have been added simply to intimidate local groups, or to impress visitors with the purported safety or status of the structure.

87 Veracini, 'Settler Collective, Founding Violence and Disavowal', 368.

88 Breslin, Exterminate with Pride, 41. 
The 97 structures analysed here also highlight something of the contours of memory that mapped the frontier for later generations, akin to Hirsch's notion of 'postmemory ${ }^{89}$ Post-memory is concerned with how second and third generations remember the critical life events of their parents and grandparents and is essentially the working of family memory through various prompts - photographs, literature, film, monuments or, in this case, physical structures and features. The heritage of a defensive frontier (fragmentary as it is) assumes particular importance in the construction of these tales. A 'fortified' house or a 'loop-holed' slab - regardless of whether it is the actual structure or the family tale of one - becomes what Slotkin labelled 'mythic icons': 'symbols ... that effect a poetic construction of tremendous economy and compression and a mnemonic device capable of evoking a complex system of historical associations by a single image or phrase'.$^{90}$ The creation of a unitary settler identity in hindsight is reminiscent of similar processes for constructing a corporate identity from the communal insecurity of a contested frontier operating in places such as South Africa. ${ }^{91}$

The legacy of this anxiety from the past is the tension around forgetting and remembering the frontier wars that has been illuminated by so many post-modern scholars in the present. ${ }^{92}$ Veracini observed that the settler colonial project invariably begins in the wilful perception of a vacuum ('virgin land' or, in Australia's case, 'terra nullius'), which is subsequently transformed into a different form of absence through demographic loss, or 'the tendency to depopulate the country of Indigenous peoples in representations' (typified by the notion of the 'dying pillow', but also in the many claims made for the inexplicable absence of Aboriginal people from the landscape). ${ }^{93}$ This is the schizophrenia of absence identified by Delrez, who argued that national self-definition in Australia 'depended from the first upon the perpetuation of a singular collective amnesia, but also on the further desire to transform this mnemonic gap into a form of historical memory.$^{94}$ In other words, although frontier violence was in many ways erased at the time of its committal, it was nonetheless also indelibly remembered through means such as the material qualities of domestic structures.

The transformation of amnesia into memory is perhaps better understood within the context of the figures for non-Aboriginal deaths on the frontier. The seemingly small percentage ( 1 per cent by our calculations) of such deaths, in fact, demonstrates the severity of the frontier wars. Australian deaths in better documented conflicts when the non-Aboriginal population was much higher, rarely attained greater percentages

89 Hirsch, 'Family Pictures' and 'The Generation of Postmemory'.

90 Slotkin, Gunfighter Nation, 26.

91 See, for example, Lester, 'Reformulating Identities'.

92 See, for example, Attwood, 'Unsettling Pasts'; Edmonds, Settler Colonialism and (Re)Conciliation; Veracini,

'Settler Collective, Founding Violence and Disavowal'.

93 Veracini, 'Settler Collective, Founding Violence and Disavowal', 368.

94 Delrez, 'Fearful Symmetries', 52-53. 
per head of population. In the Second World War the figure was 27,000, or 0.38 per cent of the population, compared to far smaller numbers for Afghanistan (41 deaths), Korea (340) or Vietnam (521). ${ }^{95}$ Even the 60,000 lives lost in the First World War amounted to only 1.5 per cent of total population. In contrast, both Loos's and Taylor's estimates for the specific regions of far north Queensland and Moreton Bay, respectively, exceed this, providing averages on the order of 2 per cent and 8 per cent. ${ }^{96}$ If the estimates of Aboriginal deaths are added, then the figures for frontier warfare have no parallel, a situation ripe for the creation of emotional dissonance around remembering and forgetting.

Far from being forgotten in the late nineteenth and early twentieth centuries, narratives of frontier conflict embodied through the architectural features of domestic buildings were codified and idealised, constructed into a political platform for a white settler nation and recycled to serve new uses as the politics of nationhood collided first with the complexities of Gallipoli and the Anzacs in the early part of the twentieth century, and second with the postcolonial movement that sought to unsettle and deconstruct settler colonialism in the late twentieth century. The resurgence of fortification narratives (which metaphorically fortify the frontier in the sense of shoring it up as a place of danger, aggression and defence) ties to wider conceptual flows about Aboriginal people, as well as the roots of white identity and Australian nationalism following Federation.

\section{Conclusion}

Our survey indicates a greater depth to the architectural materialisation of anxiety than has hitherto been articulated, even if the majority of buildings have failed to survive into the present. We therefore recognise that these data need to be further interrogated through other, complementary lines of evidence, such as recording architectural features of extant, potentially defensive structures, analysing the landscape context of particular buildings to understand other activities that may have contributed to a state of defensiveness, mapping potentially fortified structures against the context of conflict events around them, analysing regional trends in particular architectural features and researching the military or other relevant backgrounds of the builders.

In advocating any navigation of the flows of anxiety in the past and the present we consciously subscribe to a position that the events of the recent past are more important to an understanding of contemporary social politics than the longer history of 'deep time':

95 'Deaths as a Result of Service with Australian Units', Australian War Memorial, accessed 6 September 2020, www.awm.gov.au/articles/encyclopedia/war_casualties.

96 Loos, Invasion and Resistance, 193; Taylor, 'Race Relations in South East Queensland', 30. 
If archaeology in Australia were to cease concerning itself with the nation's desire for 'depth' it might rise, as it were, to the surface. By 'surface' I mean that relatively horizontal (post-1788) space or terrain across which are distributed the traces of the Aboriginal contact and post-contact experience, a terrain where duration is measured in generations (life-times) rather than millennia. ${ }^{97}$

Exploring such a surface is not simple, nor is it smooth. Investigating it questions the moorings of the stability of (white) identity, or, rather, shows the process by which such stability has been, and is being, achieved. This is perhaps one of the reasons why 'Australianness' in the twentieth and twenty-first centuries has been connected so strongly to the First World War rather than to prior events, since the coherence of the Anzac identity allows white Australia to sidestep events in the nineteenth century. The conceptualisation of the frontier wars, however, is nonetheless built on a similar notion of foundational heroism:

At those moments that buried accounts of violence break through established history, the history of settlement is beset by a twin ambivalence. On the one hand, accounting for frontier violences asserts local histories of encounter over generalising national narratives of settlement. Operating in the opposite direction, violence becomes a precondition for nationhood, associating the shedding of blood with sacrifice and elevating violent encounter into a kind of civil action. To the extent that sacrifice and violence are more commonly recognised through the Gallipoli story as inaugurating Australian nationhood, they operate within longstanding discourses of masculine nationfounding in Western liberal democracies. ${ }^{98}$

Byrne discussed the heritage of segregation as a landscape 'tense with racial foreboding, paranoia, longing and deprivation', that used a variety of physical, legislative and other means to keep groups of people separate. ${ }^{99}$ In terms of the conflict over and on the Queensland frontier the issue is not only how close (physically) people were allowed to come to one another, but how that proximity was regulated through fear and arbitrated through violence.

\section{Acknowledgements}

This research was funded through the Australian Research Council (DP160100307, The Archaeology of the Queensland Native Mounted Police). We thank architectural historian Peter Bell for pointing us towards Fanning River and military historian Rod Pratt for guidance on the tactical merits of various elements of defensive architecture.

97 Byrne, 'Deep Nation', 102.

98 Davis, 'Transforming the Frontier in Contemporary Australia', 10.

99 Byrne, 'Nervous Landscapes', 170. 


\section{References}

\section{Primary sources}

Fred Fink Collection. History of Maroochydore-Mooloolaba. Sunshine Coast Council Heritage Library.

Hain and Searight Pty Ltd. “Kilkivan” Estate', 1909. Brochure. Barcode 76751713. John Oxley Library, State Library of Queensland.

Harris, George. 'Reminiscences of My Early Days in Ipswich', F344. Fryer Library, University of Queensland.

Letterbook of Despatches to the Secretary of State for the Colonies, Item ID 17671. Queensland State Archives.

NSW Colonial Secretary Letters Relating to Moreton Bay and Queensland 1822-1860, Reels A2.22 and A2.28. Queensland State Library.

Tennant Estate Papers, George Pearce Serocold (1828-1912), D/D T 2974/7. West Glamorgan Archive Service, GB 216.

Ward Brown, Jan. 'Native Mounted Police', Jan Ward-Brown Research Notes, 2975/8, Box 5273. John Oxley Library, State Library of Queensland.

\section{Newspapers}

Australasian Sketcher with Pen and Pencil (Melbourne)

Australian Town and Country Journal (Sydney)

Balonne Beacon (St George)

Brisbane Courier

Capricornian (Rockhampton)

Central Queensland Herald (Rockhampton)

Courier-Mail (Brisbane)

Cummins and Campbell's Monthly Magazine (Townsville)

Daily Mail (Brisbane)

Daily Mercury (Mackay)

Echuca and Moama Advertiser and Farmer's Gazette

Longreach Leader

Maitland Mercury and Hunter River General Advertiser

Maryborough Chronicle, Wide Bay and Burnett Advertiser

Moreton Bay Courier (Brisbane)

Morning Bulletin (Rockhampton) 
ABORIGINAL HISTORY VOL 442020

Northern Star

Queenslander (Brisbane)

Steering Wheel and Society and Home (Brisbane)

Sydney Morning Herald

Townsville Daily Bulletin

Warwick Daily News

Wingham Chronicle and Manning River Observer

\section{Published sources}

Allingham, Anne. Taming the Wilderness: The First Decade of Pastoral Settlement in the Kennedy District. Studies in North Queensland History No. 1. Townsville: History Department, James Cook University, 1988.

Attwood, Bain. 'Unsettling Pasts: Reconciliation and History in Settler Australia'. Postcolonial Studies 8, no. 3 (2005): 243-59. doi.org/10.1080/13688790500231012.

Beardmore, George Oakes. 'Glimpses of Early Australia Part III'. Queensland Government Mining Journal September (1964): 475-79.

Bell, Peter. 'TFTA Fanning Sectors. Survey and Management Plan of European Cultural Heritage'. Report to Department of Defence, 2014.

Black, Jane. North Queensland Pioneers. Charters Towers: Queensland Country Women's Association, 1930.

Bloxsome, Herbert S. 'The Discovery, Exploration and Early Settlement of the Upper Burnett of Queensland'. Historical Society of Queensland Journal 3, no. 5 (1942): 331-50.

Bogart, Charles H. 'Fort Harrod, Kentucky: A Colonial Frontier Fort'. Fort: The International Journal of Fortification and Military Architecture 23 (1995): 3-18.

Bourke, Joanna. 'Fear and Anxiety: Writing about Emotion in Modern History'. History Workshop Journal 55 (2003): 111-33. doi.org/10.1093/hwj/55.1.111.

Breslin, Bruce. Exterminate with Pride: Aboriginal-European Relations in the TownsvilleBowen Region to 1869. Studies in North Queensland History No. 18. Townsville, Qld: Department of History and Politics, James Cook University, 1992.

Broome, Richard. 'Historians, Aborigines and Australia: Writing the National Past'. In In the Age of Mabo: History, Aborigines and Australia, edited by Bain Attwood, 54-72. Sydney: Allen \& Unwin, 1996.

Bull, David W. Short Cut to Gympie Gold: Short Stories of Tewantin and the Sunshine Coast. Yeerongpilly, Qld: F.H. Watson, 1982. 
Burke, Heather, Lynley A. Wallis, Bryce Barker, Megan J. Tutty, Noelene Cole, Iain Davidson, Elizabeth Hatte and Kelsey Lowe. 'The Homestead as Fortress: Fact or Folklore?' Aboriginal History 41 (2017): 151-77. doi.org/10.22459/AH.41.2017.07.

Byrne, Denis. 'Deep Nation: Australia's Acquisition of an Indigenous Past'. Aboriginal History 20 (1996): 82-107. doi.org/10.22459/AH.20.2011.04.

Byrne, Denis. 'Nervous Landscapes: Race and Space in Australia'. Journal of Social Archaeology 3, no. 2 (2003): 169-93. doi.org/10.1177/1469605303003002003.

Campbell Praed, Rosa. My Australian Girlhood: Sketches and Impressions of Bush Life. London: T. Fisher Unwin, 1902.

Card, Claudia. 'Rape as a Weapon of War'. Hypatia 11, no. 4 (1996): 5-18. doi.org/10.1111/ j.1527-2001.1996.tb01031.x.

Carlisle, Ronald C. 'Notes on the Architecture of Fort McIntosh and the Construction of a Blockhouse on the Beaver River in 1788'. Western Pennsylvania Historical Magazine 62, no. 1 (1979): 39-59.

Clements, Nicholas and Andrew Gregg. "'I Am Frightened Out of My Life”: Black War, White Fear'. Settler Colonial Studies 7, no. 2 (2017): 221-40. doi.org/10.1080/2201473X.2015. 1096878.

Corfield, William H. 'Reminiscences of North Queensland, 1862-1878'. Journal of the Royal Historical Society of Queensland 2, no. 2 (1923): 81-96.

Corfield, William H. Reminiscences of Queensland 1862-1899. Brisbane: A.H. Frater, 1921.

Cryle, Mark. 'A Fantastic Adventure. Reading Christison of Lammermoor'. Professional Historians Association Queensland Conference, St Lucia, Queensland, Australia. 3-4 September 2009.

Curthoys, Ann. 'Expulsion, Exodus and Exile in White Australian Historical Mythology'. Journal of Australian Studies 23 (1999): 1-19. doi.org/10.1080/14443059909387469.

Davis, Richard. 'Introduction: Transforming the Frontier in Contemporary Australia', in Dislocating the Frontier: Essaying the Mystique of the Outback, edited by Deborah Bird Rose and Richard Davis, 7-22. Canberra, ANU E Press, 2005. doi.org/10.22459/ DF.03.2006.

Delrez, Marc. 'Fearful Symmetries: Trauma and "Settler Envy" in Contemporary Australian Culture'. Miscelánea: A Journal of English and American Studies 42 (2009): 51-65.

de Satge, Oscar. Pages from the Journal of a Queensland Squatter. London: Hurst and Blackett, 1901.

Diken, Bülent and Carsten B. Lausten. 'Becoming Abject: Rape as a Weapon of War'. Body and Society 11 (2005): 111-28. doi.org/10.1177/1357034X05049853. 
Dryenfurth, Nick. 'Labor and the Anzac Legend'. Labour History 106 (2014): 163-88. doi.org/10.5263/labourhistory.106.0163.

Eden, Charles H. My Wife and I in Queensland: An Eight Years' Experience in the Above Colony. London: Longmans, Green \& Co., 1872.

Edmonds, Penelope. Settler Colonialism and (Re)Conciliation: Frontier Violence, Affective Performances, and Imaginative Refoundings. Houndmills: Palgrave Macmillan, 2016. doi.org/10.1057/9781137304544.

Evans, Raymond. “The Blood-Dimmed Tide”: Frontier Violence and Aboriginal Resistance'. In Race Relations in Colonial Queensland, edited by Raymond Evans, Kay Saunders and Kathryn Cronin, 33-46. St Lucia: University of Queensland Press, 1993.

Evans, Raymond. 'The "Darkling Plain": Impressions of Early Racial Confrontation in Frontier Violence and Aboriginal Resistance'. In Race Relations in Colonial Queensland, edited by Raymond Evans, Kay Saunders and Kathryn Cronin, 27-32. St Lucia: University of Queensland Press, 1993.

Evans, Raymond and Robert Ørsted-Jensen. “"I Cannot Say the Numbers That Were Killed”: Assessing Violent Mortality on the Queensland Frontier'. Unpublished paper delivered at 'Conflict in History', The Australian Historical Association 33rd Annual Conference, University of Queensland, 7-11 July 2014. doi.org/10.2139/ssrn.2467836.

Farrell, John. 'The Last Bullet'. In The Bulletin Reciter: A Collection of Verses for Recitation from 'The Bulletin' Sydney, edited by A. G. Stephens, 221-29. Sydney: Bulletin Newspaper Company, 1902.

Foster, Robert. "'Don't Mention the War": Frontier Violence and the Language of Concealment'. History Australia 6, no. 3 (2009): 68.1-68.15. doi.org/10.2104/ha090068.

Fox, Matt. J., comp. The History of Queensland, Its People and Its Industries. 3 vols. Brisbane: States Publishing Co., 1919-23.

Freud, Sigmund. A General Introduction to Psychoanalysis. New York: Horace Liveright, 1920. doi.org/10.1037/10667-000.

Fysh, Hudson. Taming the North, Sydney, Angus and Robertson, 1950.

Garie, Franklin. 'Australian Colonial Forts: A Short History and Gazeteer'. Fort: The International Journal of Fortification and Military Architecture 23 (1995): 19.

Gray, Jeffrey. A Military History of Australia, 3rd ed. Cambridge: Cambridge University Press, 2008.

Gray, Lucy. 'Life on the Flinders River (1868-70)'. Queensland Heritage 1, no. 2 (1965): 17-27.

Gray, Robert. Reminiscences of India and North Queensland. London: Constable and Company, 1913. 
Greenwood, Justine. 'Driving through History: The Car, The Open Road, and the Making of History Tourism in Australia, 1920-1940', Journal of Tourism History 3, no. 1 (2011): 21-37. doi.org/10.1080/1755182X.2011.575954.

Grguric, Nicholas. 'Staking a Claim: Fortified Homesteads and Their Place in Australian Settler Identity Construction'. Archaeological Review from Cambridge 25 (2010): 47-63.

Gunn, Donald. Links with the Past: A History of Early Days in Australia. Brisbane: Mills, 1937.

Hall, Thomas. The Early History of Warwick District and Pioneers of the Darling Downs, Toowoomba, Qld: Robertson and Proven, 1925.

Hill, W. R. O. Forty-five Years' Experience in North Queensland, 1861 to 1905: With a Few Incidents in England, 1844 to 1861. Brisbane: H. Pole, 1907.

Hirsch, Marianne. 'Family Pictures: Maus, Mourning and Postmemory'. Discourse 15, no. 2 (1996): 3-29.

Hirsch, Marianne. 'The Generation of Postmemory'. Poetics Today 29, no. 1 (2008): 103-28. doi.org/10.1215/03335372-2007-019.

Hodgson, Christopher P. Reminiscences of Australia: With Hints on The Squatter's Life. London: W.N. Wright, 1846.

Jack, Robert L. Northmost Australia: Three Centuries of Exploration, Discovery and Adventure in and around the Cape York Peninsula, Queensland (Volumes I and II). London: Simpkin, Marshall, Hamilton, Kent \& Co., 1921.

Kerkhove, Ray. 'Frontier War Defences of Early Queensland'. Queensland History Journal 24, no. 7 (2020): 673-90.

Kerkhove, Ray and Cathy Keys. 'On the Lookout: Defensive Surveillance of Convicts and Foreigners as a Defining Element of Early Queensland Architecture (1820s-1880s)'. Queensland History Journal 24, no. 5 (2020): 476-85.

Kerr, Rosemary. 'Through the Rear View Mirror: Landscapes, Legends and Literature on the Australian Road'. Studies in Travel Writing 17, no. 2 (2013): 188-206. doi.org/10.1080/ 13645145.2013.783960.

Kirk, Neville. "'Australians for Australia”: The Right, the Labor Party and Contested Loyalties to Nation and Empire in Australia, 1917 to the early 1930s'. Labour History 91 (2006): 95-111. doi.org/10.2307/27516154.

Lester, Alan. 'Reformulating Identities: British Settlers in Nineteenth-Century South Africa'. Transactions of the Institute of British Geographers, n.s., 23, no. 4 (1998): 515-31. doi.org/ 10.1111/j.0020-2754.1998.00515.x.

Linn, Angela J. 'An American Treasure in Fairbanks: The Rehabilitation of the Kolmakovsky Blockhouse'. Alaska Journal of Anthropology 11, no. 1 \& 2 (2013): 93-100. 
Loos, Noel. 'A Chapter of Contact: Aboriginal-European Relations in North Queensland 1606-1992'. In Race Relations in North Queensland, edited by Henry Reynolds, 4-39. Townsville, Qld: Department of History and Politics, James Cook University, 1993.

Loos, Noel. Invasion and Resistance: Aboriginal-European Relations on the North Queensland Frontier 1861-1897. Canberra: Australian National University Press, 1982.

Mann, David F., Henri D. Grissino-Mayer, Charles H. Faulkner and John B. Rehder. 'From Blockhouse to Hog House: The Historical Dendroarchaeology of the Swaggerty Blockhouse, Cocke County, Tennessee, USA'. Tree Ring Research 65, no. 1 (2009): 57-67. doi.org/10.3959/2007-4.1.

Manning, Keith W. In Their Own Hands: A North Queensland Sugar Story. Farleigh, Qld: Farleigh Co-op Sugar Milling Association, 1993.

Moore, Clive. 'Restraining Their Savage Propensities: Aboriginal-European Relations in the South Kennedy and North Leichhardt Districts of Queensland in the 1860s and 1870s'. In Race Relations in North Queensland, edited by Henry Reynolds, 83-114. Townsville, Qld: Department of History and Politics, James Cook University, 1993.

Murphy, John. Imagining the Fifties: Private Sentiment and Political Culture in Menzies' Australia. Sydney: UNSW Press, 2000.

Nahrung, Konrad. The Life of Konrad Nahrung. Jason Nahrung/Lulu.com, 2011.

Nettelbeck, Amanda and Robert Foster. 'Commemorating Foundation: A Study in Regional Historical Memory'. History Australia 3 (2010): 53.1-53.18. doi.org/10.2104/ha100053.

Prickett, Nigel. 'The Archaeology of the New Zealand Wars'. Australasian Historical Archaeology 10 (1992): 3-14.

Prickett, Nigel. 'British Army Field Fortifications of the New Zealand Wars'. Fort: The International Journal of Fortification and Military Architecture 22 (1994): 111-27.

Prickett, Nigel and Rick McGovern-Wilson. Planning a Future for New Zealand War Sites and Landscapes. Occasional Publications in Archaeology No. 1. Auckland: New Zealand Historic Places Trust, 2009.

Queensland Legislative Assembly. Report from the Select Committee on the Native Police Force and the Condition of the Aborigines Generally Together with the Proceedings of the Committee and Minutes of Evidence. Brisbane: Fairfax and Belbridge, 1861.

Reid, Gordon. 'A Nest of Hornets: The Massacre of the Fraser Family at Hornet Bank Station, Central Queensland, 1857, and Related Events'. MA thesis, The Australian National University, Canberra, 1981.

Reynolds, Henry. Frontier: Aborigines, Settlers and Land. Sydney: Allen \& Unwin, 1987.

Reynolds, Henry. 'Racial Violence in North Queensland'. In Lectures on North Queensland History Second Series, edited by Brian Dalton, 21-29. Townsville: Department of History, James Cook University, 1975. 
Richards, Jonathan. “'A Question of Necessity”: The Native Police in Queensland'. PhD thesis, School of Arts, Media and Culture, Griffith University, Brisbane, 2005.

Roberts, David. 'Bell Falls Massacre and Bathurst's History of Violence: Local Tradition and Australian Historiography'. Australian Historical Studies 26, no. 105 (1995): 615-33. doi.org/10.1080/10314619508595986.

Rowse, Tim and Emma Waterton. 'The "Difficult Heritage" of the Native Mounted Police'. Memory Studies (2018): 1-5. doi.org/10.1177/1750698018766385.

Ryan, Lyndall. 'Untangling Aboriginal Resistance and the Settler Punitive Expedition: The Hawkesbury River Frontier in New South Wales, 1794-1810'. Journal of Genocide Research 15, no. 2 (2013): 219-32. doi.org/10.1080/14623528.2013.789206.

Slotkin, Richard. Gunfighter Nation: The Myth of the Frontier in Twentieth-Century America. New York: Atheneum, 1992.

Stevenson, James B. Seven Years in the Australian Bush. Liverpool: William Potter, 1880.

Taylor, John C. 'Race Relations in South East Queensland 1840-1860'. BA Honours thesis, University of Queensland, St Lucia, 1967.

Veracini, Lorenzo. 'Settler Collective, Founding Violence and Disavowal: The Settler Colonial Situation'. Journal of Intercultural Studies 29, no. 4 (2008): 363-79. doi.org/10.1080/ 07256860802372246.

Walton, Anthony. New Zealand Redoubts, Stockades and Blockhouses, 1840-1848. DOC Science Internal Series No. 122. Wellington: Department of Conservation, 2003.

Weaver-Hightower, Rebecca. 'Geopolitics, Landscape and Guilt in Nineteenth-Century Colonial Literature'. In Geocritical Explorations: Space, Place and Mapping in Literary and Cultural Studies, edited by Robert T. Tally Jr, 123-38. New York: Palgrave Macmillan, 2011. doi.org/10.1057/9780230337930_9.

Wiltshire, Kelly, Mirani Litster and Grant Rigney. "'Necessary Self-defence?”: Pastoral Control and Ngarrindjeri Resistance at Waltowa Wetland, South Australia'. Journal of the Anthropology Society of South Australia 42 (2018): 81-114. 
This text is taken from Aboriginal History, Volume 44, 2020, edited by Crystal McKinnon and Ben Silverstein, published 2021 by ANU Press, The Australian National University, Canberra, Australia.

doi.org/10.22459/AH.44.2020.02 